\title{
Evolution of the upper mantle of the Earth's Moon: Neodymium and strontium isotopic constraints from high-Ti mare basalts
}

\author{
Gregory A. SNyder, ${ }^{1}$ Der-Chuen Lee, ${ }^{2}$ Lawrence A. TAylor, ${ }^{1}$ Alex N. Halliday, ${ }^{2}$ and Eric A. Jerde ${ }^{1}$ \\ 'Planctary Geosciences Institute, Department of Geological Sciences, University of Tennessee, Knoxville, TN 37996-1410, USA \\ ${ }^{2}$ Department of Geological Sciences, University of Michigan, Ann Arbor, MI 48109, USA
}

(Received January 14, 1994; accepted in revised form May 11, 1994)

\begin{abstract}
Isotopic studies of mare basalts have led workers to conclude that their sources are heterogeneous on both large and small scales. Furthermore, these studies have led workers to postulate that depletion within the lunar mantle occurred early in its evolution and was a result of accumulation of mafic minerals from a LREE-enriched magma ocean. High-Ti basalts from the Apollo 11 and 17 landing sites and ilmenite basalts from Apollo 12 are secondary evidence of this extreme, early depletion event. KREEPy rocks are the complementary enriched component in the Moon.

A total of fourteen high-Ti basalts have now been analyzed from the Apollo 11 landing site for neodymium and strontium isotopes. A Sm-Nd internal isochron on basalt 10058 yields an age of 3.70 $\pm 0.06 \mathrm{Ga}$, similar to ${ }^{40} \mathrm{Ar} /{ }^{39} \mathrm{Ar}$ ages of other Group B1 basalts. A compilation of all previously determined ages on Apollo 11 high-Ti basalts indicates four distinct phases of volcanism at $3.85 \pm 0.02 \mathrm{Ga}$ (Group B2), $3.71 \pm 0.02 \mathrm{Ga}$ (Group B3), $3.67 \pm 0.02 \mathrm{Ga}$ (Group B1), and 3.59 $\pm 0.04 \mathrm{Ga}$ (Group A). Wholerock Sm-Nd isotopic data for all Apollo 11 high-Ti basalts form a linear array, which yields the age of the Moon $(4.55 \pm 0.30 \mathrm{Ga})$. A similar regression of all uncontaminated high-Ti basalts from the Moon (both Apollo 11 and Apollo 17) yields an age of $4.46 \pm 0.17 \mathrm{Ga}$. Both arrays are interpreted as average source ages of the high-Ti basalts and are consistent with the formation of these sources by precipitation of cumulates from a magma ocean early in the history of the Moon.

These new strontium and neodymium isotopic data, coupled with previously published data, are consistent with a two-component model for the upper mantle of the Moon. These two components include mafic adcumulates precipitated from a magma ocean prior to $4.4 \mathrm{Ga}$ and small amounts $(<2 \%)$ of trapped, KREEPy, late-stage, magma ocean differentiates. The mafic adcumulate evolves from $4.5 \mathrm{Ga}$, with ${ }^{147} \mathrm{Sm} /{ }^{144} \mathrm{Nd}=0.318$ and ${ }^{87} \mathrm{Rb} /{ }^{86} \mathrm{Sr}=0.005$ to extremely radiogenic neodymium isotopic ratios and very unradiogenic strontium isotopic ratios. The KREEPy trapped liquid has a ${ }^{147} \mathrm{Sm} /{ }^{144} \mathrm{Nd}=0.168$ and ${ }^{87} \mathrm{Rb} /{ }^{86} \mathrm{Sr}=0.235$ and thus, evolves toward very unradiogenic neodymium and radiogenic strontium isotopic ratios. Because the KREEPy trapped liquid is enriched in both rubidium and the REEs by over an order of magnitude compared to the mafic adcumulate, trapping of even small proportions of this liquid in the adcumulate will control the radiogenic isotopic composition of the source. The apparent heterogeneity in the source regions of mare basalts could be caused by trapping of variable, yet small, proportions of this LILE-enriched liquid in the cumulate pile.
\end{abstract}

\section{INTRODUCTION}

IN THE LIGHT OF THEORIES that have resurrected the "Collision Hypothesis" for the origin of the Earth-Moon system (HARTMANN and DAVIS, 1975; MElosh, 1990), it is evident that studies of the composition of the lunar interior are important, not only in their own right, but in order to achieve a better understanding of the chemistry of the early mantle of the Earth. An appropriate window through which to view the lunar interior is the chemistry of basalts extruded onto the surface of the Moon. To this end, a comprehensive neodymium and strontium isotopic study was undertaken on high-Ti basalts from the Sea of Tranquility (Apollo 11), a study that complements earlier, ground-breaking isotopic studies of basalts from this site (PAPANASTASSIOU et al., 1977; UNRUH et al., 1984; NYQUIST and SHIH, 1992, and references therein) and more recent isotopic studies on high-Ti basalts from the Valley of Taurus-Littrow (Apollo 17 landing site; PACES et al., 1991). We compare these radiogenic isotopic data with that available in the voluminous literature on the mineralogy, petrology, chemistry, and ${ }^{40} \mathrm{Ar} /{ }^{39} \mathrm{Ar}$ systematics of high-Ti basalts from the Apollo 11 landing site, and develop a unified model of high-Ti basaltic volcanism in the Tranquillity Basin.

The origin of mare basalts is the subject of considerable study and controversy (NEAL and TAYLOR, 1992, and references therein). Three principal models have been discussed. The first is the primitive source model, which proposes that mare basalts formed by varying degrees of partial melting of primitive material of bulk Moon composition (RINGWOOD and EsSENE, 1970; GrEEN et al., 1971). This model fails to explain many of the features (e.g., negative europium anomalies) later realized to be ubiquitous in mare basalts (see the discussion in TAYLOR, 1982), and has long since been abandoned. A second model suggests that the source of the mare basalt liquids is, indeed, the primitive lunar interior, but that the ascending magmas are hybridized through assimilation of the magma-ocean residuum (i.e., urKREEP, as per WARREN and WASSON, 1979; HUBBARD and MINEAR, 1976; RINGWOOD and KESSON, 1976). This model predicts a positive correlation between incompatible elements in mare basalts and those in highlands rocks, whereas a negative correlation is actually observed (TAYLOR, 1982). The third model places the origin of the mare basalt liquids in the mafic 
cumulates formed through crystallization of the lunar magma ocean. This model was proposed by PHILPOTTS and SCHNETZLER (1970) and SMITH et al. (1970), with further development and modification by TAYLOR and JAKES (1974), WALKer et al. (1975), DRAKE and CONSOLMAGNO (1976), SHIH and SCHONFELD (1976), and NYQUIST et al. (1976). BINDER ( 1982 ) revised the magma ocean cumulate model further, by considering the effects of a convecting magma system and a trapped liquid component on the cumulate pile. This third model, albeit in various forms and consisting of differing components, successfully explains the complementary nature of the highlands and mare chemistry (BINDER, 1982; SNYDER et al., 1992). Another major advantage is that it can explain the two-stage evolution indicated by radiogenic isotopes (NYQUIST and SHIH, 1992, and references therein).

To date, there have been whole-rock chemical analyses of seventy-three mare basalt fragments from Apollo 11 (BEATY and ALBEE 1978; BEATY et al., 1979; MA et al., 1980; RHODES and BLANCHARD, 1980), and three principal groups (A, B, D) have been delineated. All of these basalts have $\mathrm{TiO}_{2}$ abundances in excess of $9 \mathrm{wt} \%$. Group A consists of high-K basalts, enriched in incompatible trace elements (Fig. 1). Group B mare basalts are divided into subgroups 1,2 , and 3. Groups B1 and B3 form a continuum of compositions, and share many of the same textural features (BEATY and AlBEE, 1978). B3 basalts display the most primitive (highest $\mathrm{Mg}$, lowest incompatible element abundances) compositions among the Apollo 11 samples. Groups B1, B2, and B3 basalts are all "low-K," but those of B2 are otherwise enriched in incompatible trace elements relative to $\mathrm{B} 1$ and $\mathrm{B} 3$ basalts. The least-represented basalts are from Group D, of which only three examples have been described (BEATY et al., 1979). These tiny samples ( two are $<50 \mathrm{mg}$; the third is $187 \mathrm{mg}$ ) are rich in incompatible trace elements such as the REEs, comparable to the Group A basalts, but are low in potassium like the B3 and B2 samples. Such a signature is unusual for lunar rocks, which generally display a close correspondence between potassium and the REEs (the so-called KREEP component).

Trace-element studies of the high-Ti basalts have yielded information on the projected chemical composition of sources and on near-surface processes such as fractional crystallization, but cannot give information on the timing of melting and crystallization events. For such purposes, radiogenic isotope studies have proven fruitful. Isotopic studies indicate strong depletion of LILE in the upper mantle of the Moon within $200 \mathrm{~m}$.y. of its formation. High-Ti mare basalts can be modelled as melts of depleted clinopyroxene-pigeoniteolivine-ilmenite adcumulates from a lunar magma ocean ( $\mathrm{LMO}$ ) which contain $<2 \%$ intercumulus trapped liquid. Ilmenite, which is required in the source, does not become a liquidus phase in the LMO until it is more than $90 \%$ crystallized, at which point the residual LMO liquid has become extremely LILE-enriched (KREEPy) with low $\mathrm{Sm} / \mathrm{Nd}$ and high Rb/Sr (SNYDER et al., 1992). This KREEPy trapped liquid, though a volumetrically minor component of the cumulate pile, controls the LILE abundances in the source. With time, the mafic adcumulate rapidly diverges from a chondritic reference reservoir (i.e., CHUR) to elevated, pos- itive $\epsilon_{\mathrm{Nd}}$ values, whereas the trapped liquid also diverges from CHUR, but to more negative $\epsilon_{\mathrm{Nd}}$ values. Even small proportions of this trapped liquid will greatly effect the "initial" isotopic ratios of basalts derived from the upper mantle of the Moon.

\section{ANALYTICAL METHODS AND DATA PRESENTATION}

Samples were crushed in acetone in a boron carbide mortar under a flow of better than class 100 air. Two of the samples ( 10050 and 10058 ) were selected for internal mineral isochron dating. One of these samples (10058) included analyses of a whole-rock and three mineral separates, whereas the other sample (10050) included only two points, a whole-rock and a plagioclase separate. For sample 10058. approximately $15 \mathrm{mg}$ was used for whole-rock analyses and the remainder was separated into magnetic fractions on a Frantz isodynamic separator. These magnetic splits were then handpicked to achicve $>95 \%$ pure plagioclase, pyroxene, and ilmenite separates.

Samples were dissolved in $\mathrm{HF}, \mathrm{HNO}_{3}$, and $\mathrm{HCl}$, and isotope dilution measurements made on a $10-15 \%$ split of this solution with ${ }^{87} \mathrm{Rb}^{-84} \mathrm{Sr}$ and ${ }^{149} \mathrm{Sm}-{ }^{150} \mathrm{Nd}$ mixed spikes. Total-process blanks for chemical procedures were always less than $10 \mathrm{pg}$ rubidium, $120 \mathrm{pg}$ strontium, $10 \mathrm{pg}$ samarium, and $50 \mathrm{pg}$ neodymium. Strontium and neodymium isotopic data were obtained by multidynamic analysis on a VG Sector multicollector mass spectrometer. All strontium and neodymium isotopic analyses are normalized to ${ }^{86} \mathrm{Sr} /{ }^{88} \mathrm{Sr}=0.1194$ and ${ }^{146} \mathrm{Nd} /{ }^{144} \mathrm{Nd}=0.7219$, respectively. Analyses of SRM 987 strontium and La Jolla neodymium standards were performed throughout this study and gave weighted averages (at the $95 \%$ confidence limit, external precision ) of ${ }^{87} \mathrm{Sr} /{ }^{86} \mathrm{Sr}=0.710250 \pm 0.000011$, and ${ }^{143} \mathrm{Nd} /$ ${ }^{144} \mathrm{Nd}=0.511854 \pm 0.000011$, respectively. Internal, within-run, statistics are almost always of higher precision than the external errors (see Tables 2 and 3 for within-run statistics of samples which are comparable to that of the standards). All isotope dilution measurements utilized static mode multicollector analyses.

By convention, the neodymium isotopic data are also presented in Tables 2 and 3 in epsilon units, deviation relative to a chondritic uniform reservoir, CHUR (DEPAOLO, 1976):

$$
\begin{aligned}
& \epsilon_{\mathrm{Nd}}=\left[\left({ }^{143} \mathrm{Nd} /{ }^{144} \mathrm{Nd}_{\text {sample }}{ }^{143} \mathrm{Nd} /{ }^{144} \mathrm{Nd}_{\text {CHUR }}\right) /\right. \\
& \left.{ }^{143} \mathrm{Nd} /{ }^{144} \mathrm{Nd} \mathrm{CHUR}_{\text {R }}\right] \times 10^{4} .
\end{aligned}
$$

Model ages (or single-stage evolution ages) have been calculated for both neodymium and strontium isotopes and are given under the headings $T_{C H U R}$ and $T_{\text {LUNI }}$, respectively, in Tables 2 and 3, where,

$$
T_{\text {LUNI }}=1 / \lambda \times \ln \left[\left(\left({ }^{87} \mathrm{Sr} /{ }^{86} \mathrm{Sr}-0.69903\right) /{ }^{87} \mathrm{Rb} /{ }^{86} \mathrm{Sr}\right)+1\right]
$$

and

$$
\begin{aligned}
T_{\text {CHUR }}=1 / \lambda \times \ln \left[\left({ }^{143} \mathrm{Nd} /{ }^{144} \mathrm{Nd}-\right.\right. & 0.512638) / \\
& \left.\left({ }^{147} \mathrm{Sm} /{ }^{144} \mathrm{Nd}-0.1966\right)+1\right] .
\end{aligned}
$$

The $T_{\text {LUNI }}$ model age is determined relative to a suggested lunar initial ${ }^{87} \mathrm{Sr} /{ }^{86} \mathrm{Sr}_{r}-\mathrm{LUNI}=0.69903$ at $4.55 \mathrm{Ga}$ (NYQUIST et al., 1973). The $T_{\text {CHUR }}$ model age is determined, relative to a present-day chondritic uniform reservoir (CHUR) with ${ }^{143} \mathrm{Nd} /{ }^{144} \mathrm{Nd}=0.512638$ and ${ }^{147} \mathrm{Sm} /{ }^{144} \mathrm{Nd}=0.1966$. Errors in the model ages are estimated from consideration of errors in the parent-daughter ratios and measured isotopic ratios. Errors in isochron ages are 2-sigma (YORK, 1969) of the scatter as calculated in the ISOPLOT program of LUDWIG (1990).

\section{NATURE OF HIGH-Ti BASALTIC VOLCANISM AT MARE TRANQUILLITATIS}

\section{Age Constraints on Volcanic Episodicity and Persistence}

High-Ti basaltic volcanism in the Tranquillitatis Basin persisted for at least 250 million years and possibly up to 400 million years (StetTler et al., 1974). Previous ${ }^{40} \mathrm{Ar} /{ }^{39} \mathrm{Ar}$, 
Table 1: Geochronological Information (in Ga) on Apollo 11 High-Ti Mare Basalts

\begin{tabular}{|c|c|c|c|c|c|c|}
\hline Sample & Group & ${ }^{40} \mathrm{Ar}-{ }^{39} \mathrm{Ar}$ & $\mathbf{R b}-\mathbf{S r}$ & Sm-Nd & Weight. Ave. & Ref. \\
\hline \multicolumn{7}{|l|}{ High-K } \\
\hline 10017 & A & $3.63 \pm 0.11$ & \multirow{2}{*}{$3.56 \pm 0.05$} & & \multirow{2}{*}{$\begin{array}{l}3.57 \pm 0.04 \\
3.53 \pm 0.03\end{array}$} & \multirow{2}{*}{$\begin{array}{c}1,2,3 \\
1,4\end{array}$} \\
\hline 10022 & A & $\begin{array}{l}3.54 \pm 0.06 \\
3.53 \pm 0.04\end{array}$ & & & & \\
\hline 10024 & A & $>3.4 \overline{4} \pm 0.05$ & \multicolumn{2}{|l|}{$3.59 \pm 0.07$} & \multirow{8}{*}{$\begin{array}{l}3.59 \pm 0.07 \\
3.55 \pm 0.08 \\
3.53 \pm 0.06 \\
3.41 \pm 0.04 \\
3.60 \pm 0.04 \\
3.65 \pm 0.06 \\
3.65 \pm 0.02 \\
3.59 \pm 0.02\end{array}$} & \multirow{8}{*}{$\begin{array}{c}1,2 \\
1 \\
1 \\
1 \\
1,2 \\
1,2 \\
1,2 \\
1,2,3\end{array}$} \\
\hline 10031 & A & $3.55 \pm 0.08$ & & & & \\
\hline 10032 & A & $3.53 \pm 0.06$ & & & & \\
\hline 10049 & A & $3.41 \pm 0.04$ & & & & \\
\hline 10057 & A & $>3.3 \overline{6}+0.04$ & $3.60+0.04$ & & & \\
\hline 10069 & A & $>3.45+0.04$ & $3.65 \pm 0.06$ & & & \\
\hline 10071 & A & $3.47 \pm \overline{0} .06$ & $3.65 \pm 0.02$ & & & \\
\hline 10072 & A & $3.57 \pm 0.05$ & $\begin{array}{l}3.62 \pm 0.05 \\
3.69 \pm 0.11\end{array}$ & $3.57 \pm 0.03$ & & \\
\hline \multicolumn{7}{|l|}{ Low-K } \\
\hline 10044 & B1 & $3.66 \pm 0.04$ & \multirow{2}{*}{\multicolumn{2}{|c|}{$3.67 \pm 0.07$}} & \multirow{3}{*}{$\begin{array}{l}3.66 \pm 0.03 \\
3.69 \pm 0.03 \\
3.66 \pm 0.03\end{array}$} & \multirow{3}{*}{$\begin{array}{c}1,2 \\
4 \\
1,2,3,5^{*}\end{array}$} \\
\hline 10047 & B1 & $3.69 \pm 0.03$ & & & & \\
\hline 10058 & B1 & $3.66 \pm 0.03$ & \multirow{2}{*}{$\begin{array}{l}3.61 \pm 0.10 \\
3.60 \pm 0.20 \\
3.81 \pm 0.08\end{array}$} & $3.70 \pm 0.06$ & & \\
\hline $\begin{array}{l}10003 \\
10029\end{array}$ & $\begin{array}{l}\text { B2 } \\
\text { B2 }\end{array}$ & $\begin{array}{l}3.85 \pm 0.03 \\
3.83 \pm 0.03\end{array}$ & & & $\begin{array}{l}3.85+0.03 \\
3.83 \pm 0.03\end{array}$ & 1,2 \\
\hline 10062 & B2? & $3.79 \pm 0.06$ & $3.97 \pm 0.11$ & $3.88 \pm 0.06$ & $3.87 \pm 0.03$ & 1,3 \\
\hline 10020 & B3 & $3.72 \pm 0.04$ & & & $3.72 \pm 0.04$ & 1 \\
\hline 10045 & B3 & $3.71+0.03$ & & & $3.71 \pm 0.03$ & 3 \\
\hline 10050 & B3? & $3.70 \pm 0.03$ & & & $3.70 \pm 0.03$ & 1 \\
\hline 10092 & B3 & & & & & \\
\hline
\end{tabular}

All ages calculated using the following decay constants: $\lambda^{40} \mathrm{~K}=5.81 \times 10^{-11} \mathrm{yr}^{-1}, \lambda^{87} \mathrm{Rb}=$ $1.402 \times 10^{-11} \mathrm{yr}^{-1}$, and $\lambda^{147} \mathrm{Sm}=6.54 \times 10^{-12} \mathrm{yr}^{-1}$.

Weighted Average Ages:

$A=3.59+.04 \mathrm{Ga}$

$\mathrm{B1}=3.67 \pm .02 \mathrm{Ga}$

$\mathrm{B} 2=3.85+.02 \mathrm{Gr}$

$\mathrm{B} 2=3.85 \pm .02 \mathrm{Ga}$
$\mathrm{B3}=3.71 \pm .02 \mathrm{Ga}$

References: 1 = GUGGISBERG et al (1979), 2 = PAPANASTASSIOU and WASSERBURG (1971), 3 = PAPANASTASSIOU et al. (1977), 4 = STETTLER et al. (1974), 5 = NYQUIST (1977),

* this work.

$\mathrm{Rb}-\mathrm{Sr}$, and $\mathrm{Sm}-\mathrm{Nd}$ age determinations for the high-Ti basalts from Apollo 11 have been recalculated, using the decay constants of STEIGER and JAEGER (1977) for all systems except $\mathrm{Rb}-\mathrm{Sr}$ (Table 1). For Rb-Sr, we have used a $\lambda_{{ }^{87} \mathrm{Rb}}$ of 1.402 $\times 10^{-11} \mathrm{y}^{-1}$ as suggested by MINSTER et al. (1982) and NYQUis I et al. (1986). This revised decay constant for rubidium is based on the convergence of ages for $\mathrm{Rb}-\mathrm{Sr}$ wholerock data and $\mathrm{U}-\mathrm{Th}-\mathrm{Pb}$ data from chondritic meteorites (MINSTER et al., 1982). Throughout the following discussion, the lunar basalt classification scheme of NEAL and TAYLOR (1992) is used.

Group A basalts are relatively high in $\mathrm{K}_{2} \mathrm{O}(>0.3 \mathrm{wt} \%$; Fig. 1) and definc the youngest volcanic episode ( $3.59 \pm 0.04$ $\mathrm{Ga}$ ). Groups B1, B2, and B3 basalts are low-K varieties ( $\leq 0.12$ oxide $w t \%$; Fig. 1) and exhibit a range of eruption ages from 3.85 to $3.67 \mathrm{Ga}$. Groups $\mathrm{B} 1$ and $\mathrm{B} 3$ are similar in age ( $3.67 \pm 0.02 \mathrm{Ga}$ vs. $3.71 \pm 0.02 \mathrm{Ga}$, respectively). Group B2 basalts are, by far, the most ancient expression of volcanic activity at the Apollo 11 landing site $(3.85 \pm 0.02 \mathrm{Ga})$, and are the oldest of all high-Ti basalts discovered so far.

A plot of ${ }^{147} \mathrm{Sm} /{ }^{144} \mathrm{Nd}$ vs. ${ }^{143} \mathrm{Nd} /{ }^{144} \mathrm{Nd}$ for the mineral splits and the whole-rock split (Fig. 2, Table 2) from sample 10058 (a Group B1 basalt) yields an age of $3.70 \pm 0.06 \mathrm{Ga}$, within analytical uncertainty of previous ${ }^{40} \mathrm{Ar} /{ }^{39} \mathrm{Ar}$ determinations for this basalt type. A Rb-Sr mineral-isochron for this sample yields a similar age $(3.71 \pm 0.04 \mathrm{Ga})$ when ilmenite is not included. Because ilmenite has the highest $\mathbf{R b}$ /
Sr ratio of either the minerals or the whole-rock, it will, to a great extent, control the slope of the line, and thus, the age. The inclusion of ilmenite (Fig. 3) yields an age of $3.61 \pm 0.10$ $\mathrm{Ga}$. While this age does overlap the Sm-Nd mineral-isochron age, there seems to be evidence of resetting of the Rb-Sr systematics of this sample. However, this resetting event cannot be due to later meteoritic bombardment as the ${ }^{40} \mathrm{Ar} /{ }^{39} \mathrm{Ar}$ systematics (which should be more readily disturbed) yield an age for this rock which is higher than the Rb-Sr age.

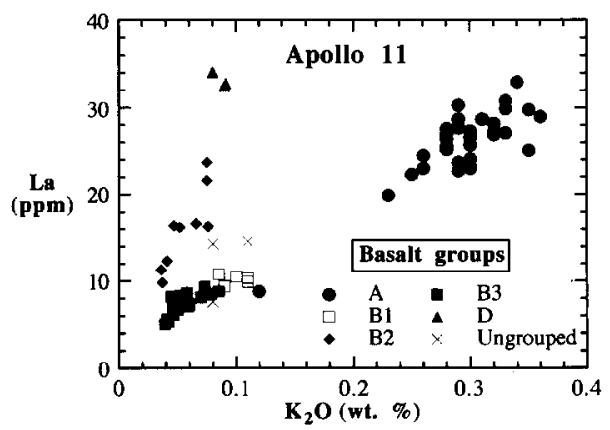

FIG. 1. La vs. $\mathrm{K}_{2} \mathrm{O}$ for Apollo 11 mare basalts showing the distribution of the various groups. Note the continuous trend for Groups B3 and B1 basalts and the nearly vertical array of B2 and D basalts. 


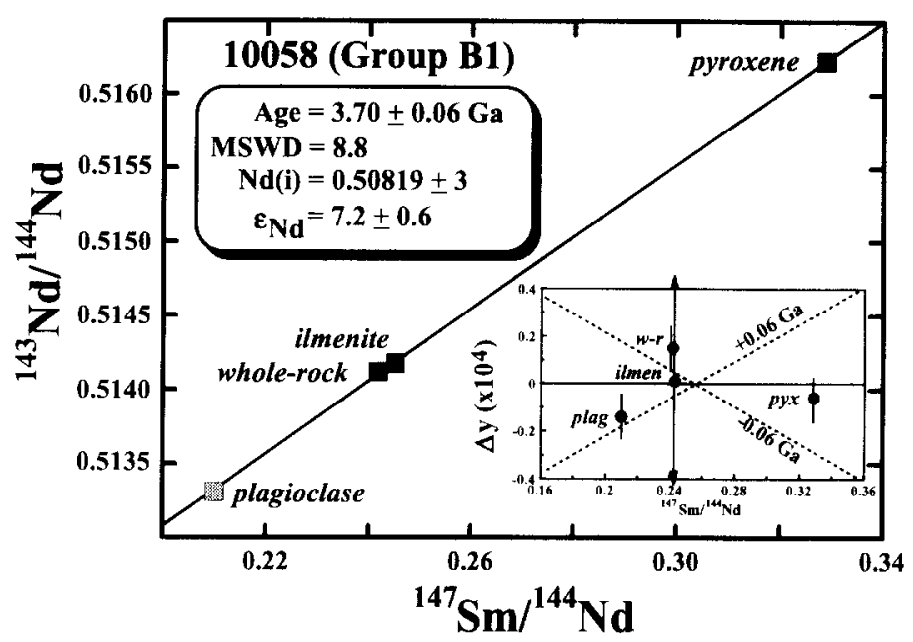

FIG. 2. Sm-Nd mineral isochron for 10058. MSWD is the mean of standard weighted deviates and indicates whether the scatter in the line is due to analytical error or due to true differences in measured values for the ratios. The higher the MSWD the more likely that the scatter is not due simply to analytical error. The inset exhibits the deviation of each datum from the "best-fit" line in units of $10^{4}$.

\section{Petrography}

The petrography of the Apollo 11 mare basalt groups has been described in detail previously (BEATY and ALBEE, 1978, 1980; BEATY et al., 1979; JERDE et al., 1994); only the basic features will be summarized here. The Group A basalts generally have been referred to as Apollo 11 high-K basalts and are distinct from other basalts present at the site. All tend to be fairly fine-grained and vesicular, although wide ranges of grain sizes and textures are present. Both porphyritic and nonporphyritic types are found, with the latter being more prevalent. The nonporphyritic basalts are approximately $25 \%$ plagioclase, $15 \%$ ilmenite, $50 \%$ pyroxene, and $10 \%$ fine-grained mesostasis, consisting of plagioclase, cristobalite, and glass. Accessory amounts of olivine, troilite, phosphate, ulvöspinel, tranquillityite, and Fe-metal are also seen. A seriate grain size ranging from $30 \mu \mathrm{m}$ to $250 \mu \mathrm{m}$ is observed among the suite, and the modal abundance does not vary significantly between the two extremes. Textures range from "antiophitic", with plagioclase enclosing smaller pyroxene grains, to subophitic. The porphyritic Group A basalts are less common, and have an average grain size of $\sim 150 \mu \mathrm{m}$ and numerous spherical vesicles up to $3 \mathrm{~mm}$ across. Pyroxene phenocrysts arc up to twice the size of groundmass minerals. These phenocrysts are intergrown with coarse ilmenite grains, and olivine cores are present in some of the phenocrysts. Armalcolite grains up to $\sim 350 \mu \mathrm{m}$ are sparse.

The Group B basalts of Apollo 11 were originally termed "low-
K" based upon early analyses (e.g., ALBEE and CHODOS, 1970; COMPSTON et al., 1970; GAST et al., 1970) and were later shown to span approximately 200 m.y. in age (PAPANASTASSIOU et al., 1977; GEISS et al., 1977), precluding their formation as a single unit. BEATY and ALBEE (1978) established that three subgroups exist, termed B1, $\mathrm{B} 2$, and $\mathrm{B} 3$, based upon textural and compositional considerations. Group B1 basalts are coarse-grained $(\sim 800 \mu \mathrm{m})$ and subophitic. Minerals present are $\sim 35 \%$ plagioclase, $45 \%$ pyroxene, $13 \%$ ilmenite, $6 \%$ cristobalite, and accessory troilite, Fe-metal, ulvöspinel, olivine, apatite, tranquillityite, glass, and K-Ba-feldspar. The pyroxene is present as $1-2 \mathrm{~mm}$ sector-zoned crystals, with interstitial plagioclase. Ilmenite is anhedral and often shows lobate intergrowths with pyroxene and plagioclase.

Group B3 basalts are essentially the same age as the B1 basalts, but are finer-grained $(\sim 200 \mu \mathrm{m})$. Textures range from intergranular to ophitic with a network of plagioclase laths, either enclosing small pyroxene grains, or itself surrounded by large pyroxene grains. Group B3 basalts have approximately the same modes as Group B1, except for the presence of up to $5 \%$ olivine phenocrysts and less cristobalite (3-5\%). Ilmenite is dominantly acicular, although equant, blocky grains arc present in one B3 samplc (10045), and occasional lobate intergrowths are characteristic of Group B1 basalts.

The basalts of Group B2 are significantly older, by $\sim 150 \mathrm{Myr}$, than the rocks of Groups B3 and B1 (Table 1). The grain size is intermediate between that of $\mathrm{B} 1$ and $\mathrm{B} 3$ basalts $(\sim 500 \mu \mathrm{m})$, and

Table 2: Rb-Sr and Sm-Nd Abundance and Isotopic Data for whole-rocks and mineral separates of Apollo 11 High-Ti Mare Basalts

\begin{tabular}{|c|c|c|c|c|c|c|c|c|c|c|}
\hline \multirow{2}{*}{ Sample } & \multirow[t]{2}{*}{ Group } & \multirow[t]{2}{*}{ wt.(mg) } & \multirow{2}{*}{$\begin{array}{c}\mathrm{Rb} \\
\text { (ppm) }\end{array}$} & \multirow{2}{*}{$\begin{array}{c}\mathrm{Sr} \\
(\mathrm{ppm})\end{array}$} & \multirow[t]{2}{*}{${ }^{87} \mathrm{Rb} /{ }^{86} \mathrm{Sr}^{1}$} & \multirow[t]{2}{*}{${ }^{87} \mathrm{Sr}^{86} \mathrm{Sr}^{2}$} & \multirow{2}{*}{$\begin{array}{c}\mathrm{Sm} \\
(\mathrm{nnm})\end{array}$} & \multicolumn{2}{|c|}{$\mathrm{Nd}^{147} \mathrm{Sm}^{144} \mathrm{Nd}^{*}$} & \multirow[t]{2}{*}{${ }^{143} \mathrm{Nd}^{\prime}{ }^{144} \mathrm{Nd}^{2}$} \\
\hline & & & & & & & & $(\mathrm{ppm})$ & & \\
\hline 10050,162 & B3 & 20 & 0.706 & 183 & 0.0112 & $0.699712 \pm 13$ & 12.3 & 30.2 & 0.2462 & $0.514237 \pm 09$ \\
\hline plag & & 16 & 0.234 & 480 & 0.00140 & $0.699222+11$ & 2.69 & 7.41 & 0.2193 & $0.513551 \pm 06$ \\
\hline 10058,189 & B1 & 15 & 1.42 & 193 & 0.0212 & $0.700306 \pm 14$ & 21.9 & 54.8 & 0.2418 & $0.514120 \pm 07$ \\
\hline plag & & 19 & 0.314 & 506 & 0.00178 & $0.699269 \pm 14$ & 2.93 & 8.45 & 0.2099 & $0.513311 \pm 09$ \\
\hline pyx & & 36 & 0.0725 & 27.5 & 0.00759 & $0.699585 \pm 14$ & 4.10 & 7.55 & 0.3287 & $0.516226+08$ \\
\hline ilm & & 38 & 0.643 & 54.6 & 0.0341 & $0.700942 \pm 10$ & 7.34 & 18.3 & 0.2431 & $0.514138 \pm 79$ \\
\hline
\end{tabular}

\footnotetext{
${ }^{1}$ Errors are $<0.6 \%$ relative for all analyses.

${ }^{2}$ Absolute errors in measured ${ }^{87} \mathrm{Sr} /{ }^{86} \mathrm{Sr}$ and ${ }^{143} \mathrm{Nd} /{ }^{144} \mathrm{Nd}$ are quoted as 2-sigma of the mean (internal precision)

"Errors are always $<0.1 \%$ relative.
} 


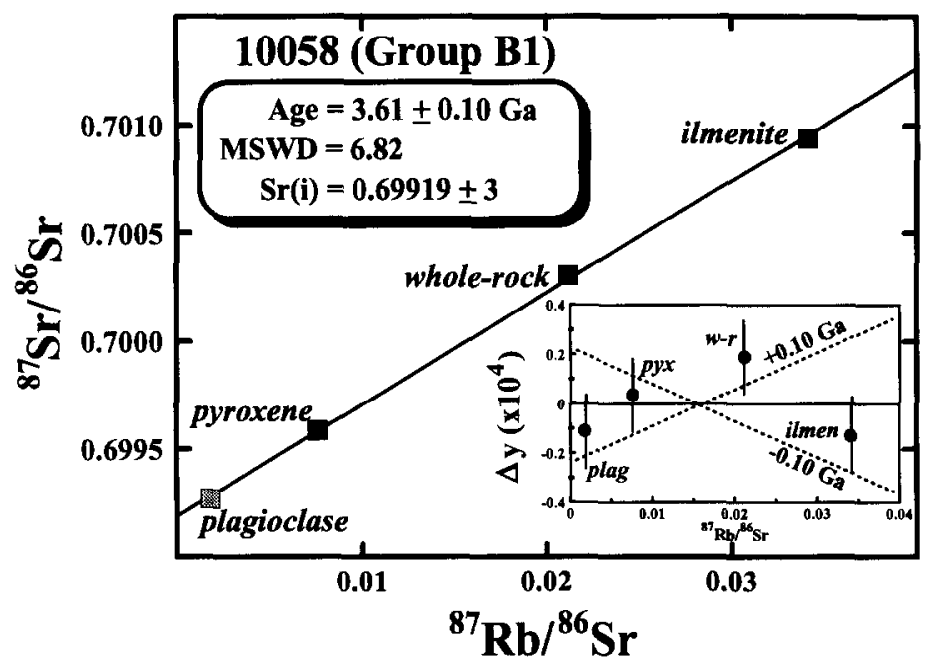

FlG. 3. Rb-Sr mineral isochron for 10058. The inset exhibits the deviation of each datum from the "best-fit" line in units of $10^{4}$.

ophitic, with $0.1-0.4 \mathrm{~mm}$ plagioclase laths set in much larger pyroxene grains, occasionally over $2 \mathrm{~mm}$ across. The approximate modes are $35 \%$ plagioclase, $50 \%$ pyroxene, $15 \%$ ilmenite, with accessory olivine, cristobalite, phosphate, troilite, Fe-metal, ulvöspinel, and tranquillityite. The plagioclase is evenly distributed through the sample, as is ilmenite. When observed, olivine is usually confined to the cores of the pyroxene.

Group D basalts are as yet only represented by three fragments from the Apollo 11 bulk sample. The three samples have masses of 26, 41, and $187 \mathrm{mg}$ (BEATY et al., 1979), so that some textural variability may be the result of sample heterogeneities. Grain size ranges from 300 to $500 \mu \mathrm{m}$, and the samples have an intersertal to subophitic texture similar to that of the Group A basalts. Plagioclase comprises $\sim 32 \%$ of the sample, pyroxene $50 \%$, and ilmenite $12 \%$. The amount of olivine varies from $<0.5 \%$ to nearly $4 \%$, and cristobalite varies from $\sim 1.5 \%$ to $4 \%$. Accessory phases include spinel, ulvöspinel, phosphate, troilite, Fe-metal, baddeleyite, tranquillityite, glass, and $\mathrm{K}, \mathrm{Ba}$-feldspar. The phosphate phases include whitlockite and are present in amounts up to $0.75 \%$.

\section{Chemistry}

The Apollo 11 basalt groups are most clearly discriminated, using a lanthanum vs. $\mathrm{K}_{2} \mathrm{O}$ variation diagram (Fig. 1). In this diagram, a continuum between $\mathrm{B} 3$ and $\mathrm{B} 1$ is seen, as is the coherence of the Group A basalts. The three Group D samples occupy a region of similar lanthanum content as the Group A basalts, but contain $<0.1 \%$ $\mathrm{K}_{2} \mathrm{O}$, whereas the members of Group $A$ are often in excess of $0.3 \%$ $\mathrm{K}_{2} \mathrm{O}$. The $\mathrm{B} 2$ samples are distributed in the region between the $\mathrm{D}$ and $B 3 / B 1$ ranges.

It has been suggested that each of the basalt groups of Apollo 11 represents a single, individual flow (BEATY and ALBEE, 1980). This is an unlikely model, because the individual basalt groups represent chemical compositions which are too variable to be related by simple fractionation, as successive volcanic flows might be. Furthermure, these basalts exhibit a wide range of crystallization ages. However, Groups B3 and B1 can be related to one another by fractional crystallization. The possibility that Groups B1 and B3 are related was briefly discussed by BEATY et al. (1979). Fractionation calculations, using a composition taken as the "most primitive" (fine-grained sample with no phenocrysts, the highest $\mathrm{Mg} \#\left[=\mathrm{Mg}^{21} /\left(\mathrm{Mg}^{2+}\right.\right.$ $\left.\left.+\mathrm{Fe}^{2+}\right)\right]$, highest incompatible elements, and lowest incompatible elements) Group B3 basalt composition successfully produce the "most evolved" BI basalt after approximately $40 \%$ crystallization (JERDE et al., 1992a, 1994). Relating these two groups to a single magma system is consistent with the essentially identical ages deter- mined for these two groups $(\mathrm{B} 1=3.67 \pm 0.02 \mathrm{Ga}$ and $\mathrm{B} 3=3.71$ $\pm 0.02 \mathrm{Ga}$ ), an "age" shared by no other group of Apollo 11 basalts.

Among the other low-K basalts of Apollo 11 (Groups B2 and D), the $\mathrm{B} 2$ basalts are the only ones to have been dated and are the oldest basalts from Apollo 11 at $3.85 \mathrm{Ga}$. These form a nearly vertical array in Fig. 1, characterized by variation in REE content, but little change in potassium. This apparent decoupling of potassium and the REEs is of interest, due to its comparative rarity in lunar samples and is explained by the accumulation of the REE-rich, K-poor mineral whitlockite. In fact, JERDE et al. (1992a, 1994) have successfully modelled the B2 and D basalts by simple addition of $0.27 \mathrm{wt} \%$ and $0.54 \mathrm{wt} \%$ whitlockite, respectively, to a model B1-B3-type magma. Therefore, it is suggested that a single magma type is responsible for the $\mathrm{B} 2$ and $\mathrm{D}$ basalts, the principal difference between the two being the amount of whitlockite present in the samples. This whitlockite could have been accumulated in the latest stages of crystallization or could have been added later, due to the upward percolation of metasomatic fluids (as per NEAL and TAYLOR, 1989). The possibility of these two groups being related also was briefly discussed by BEATY et al. (1979). It also was pointed out by BEATY and ALBEE (1978) that the Group D basalts may be from lower in the stratigraphic column, along with Group B2 basalts. If the principal difference between the two groups is a varying amount of whitlockite (coupled with small percentages of fractional crystallization), then the age of the D basalts should be that of the B2 basalts, namely $\sim 3.85 \mathrm{Ga}$.

The ages of the B3 and B1 basalts are $\sim 3.69 \mathrm{Ga}$, and those of Group B2 are $3.85 \mathrm{Ga}$, precluding a direct connection. Small amounts of whitlockite do not effect the major-element balance of a rock. The major element compositions of the $\mathrm{B} 2$ and $\mathrm{D}$ samples are not significantly different from each other, while they are higher in $\mathrm{Al}_{2} \mathrm{O}_{3}$ and $\mathrm{P}_{2} \mathrm{O}_{5}$, lower in $\mathrm{TiO}_{2}$, and possess a lower $\mathrm{Mg \#}$ than the $\mathrm{B} 3$ basalts. This is consistent with the $\mathrm{B} 2$ and $\mathrm{D}$ basalts originating through prior melting of the B3/B1 source. Thus, all of the Apollo 11 low-K basalts may have the same ultimate source (JERDE et al., 1992a, 1994).

The Group A basalts lie roughly along the trend shown by the B3 and B1 basalts in Fig. 1. The three groups B3, B1, and A are not related by simple mixing, however. Most major elements do not show linear trends between the three groups, as would be expected if mixing is responsible for generating such compositions. Nor can the Group $\mathrm{A}$ basalts be related to $\mathrm{B} 3 / \mathrm{B} 1$ by fractionation. The incompatible trace elements are enriched relative to those of the B3/B1 rocks (26.5 ppm lanthanum vs. $9.9 \mathrm{ppm}$ lanthanum in B1) which would indicate significant fractionation $(\sim 65 \%)$, but $\mathrm{Mg} \#$ in the Group A basalts is higher than that in the B1 basalts. Further, Group A samples are considerably younger ( $3.59 \mathrm{Ga}$ vs. $3.67 \mathrm{Ga}$ for the youngest low-K basalts at Apollo 11). JERDE et al. (1992b, 1994) have postulated that the Type A basalts may not be indigenous to the Apollo 11 site and their petrogenesis will not be discussed further. 

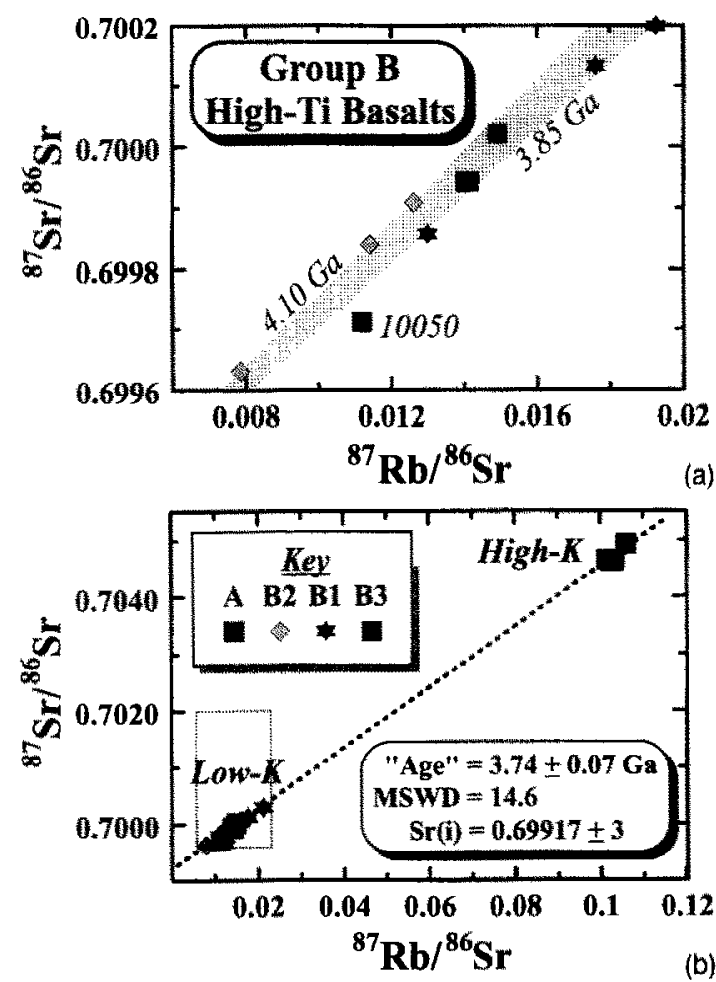

Fig. $4 .{ }^{87} \mathrm{Rb} /{ }^{86} \mathrm{Sr}$ vs. ${ }^{87} \mathrm{Sr} /{ }^{86} \mathrm{Sr}$ for Apollo $1 /$ high-Ti basalt wholerocks. a) low-K (Groups B1, B2, and B3) high-Ti basalts within a reference field defined by lines yielding ages of $4.10 \mathrm{Ga}$ (Group B2) and $3.85 \mathrm{Ga}$ (Group $\mathrm{Bi}$ ). This array converges at the $y$-intercept and give an "initial ratio" of $0.69916 \pm 8$. The previously unclassified basalt, 10050, lies outside of this array. b) All samples yield a "mixing isochron" with an "age" of $3.74 \pm 0.07 \mathrm{Ga}$ and an initial ratio of $0.69917 \pm 3$

\section{NEODYMIUM AND STRONTIUM ISOTOPIC RESULTS ON WHOLE ROCKS}

Ten new samples were analyzed for $\mathrm{Sm}-\mathrm{Nd}$ (as well as Rb$\mathrm{Sr}$, in this study. PAPANASTASSIOU et al. (1977) analyzed sample 10062 (a Group B2) and 10072 (a Group A), and UNRUH et al. (1984) reanalyzed these two samples as well as two others, 10003 (another Group B2) and 10071 (another Group A) for Sm-Nd. This means that a total of fourteen high-Ti basalts from Mare Tranquillitatis have been analyzed for both $\mathrm{Sm}-\mathrm{Nd}$ and $\mathrm{Rb}-\mathrm{Sr}$. Prior to the present study, no samples from types B1 and B3 had been analyzed for both neodymium and strontium isotopes.

$\mathrm{Rb}-\mathrm{Sr}$ isotopic data for all of the Apollo 11 high-Ti basalts define a line which yields an age of $3.74 \mathrm{Ga} \pm 0.07 \mathrm{Ga}$ (Fig. 4b). However, this line is essentially a two-point "isochron," with the two points being the high-K (Group A) and low-K (Groups B1, B2, and B3) high-Ti basalts. Furthermore, as mentioned above and in JERDE et al. (1994), the Group A basalts are vastly different both in age and genesis from the low-K basalts. Thus, the line in Fig. $4 b$ is probably a mixing array between younger Group $A$ basalts (3.59 Ga) and older low-K basalts (ranging in age from 3.67 to $3.85 \mathrm{Ga}$ ), and has no real age significance. The low-K basalts alone plot within an array defined by reference lines of $3.85 \mathrm{Ga}$ and 4.10 Ga (Fig. 4a). This array converges at the y-intercept yielding a fairly. well-defined ${ }^{87} \mathrm{Sr} /{ }^{86} \mathrm{Sr}$ "initial ratio" of $0.69916 \pm 8$. This ratio appears to be realistic as it encompasses individually calculated initial ratios for each low-K basalt sample (Table 3 ). The "age" range of this array is similar to a Rb-Sr age obtained by PACES et al. (1991) on a selected group of Apollo 17 basalts $(4.02 \pm 0.05 \mathrm{Ga})$. However, the scatter in this array as compared to that of PACES

Table 3: Whole-Rock Rb-Sr and Sm-Nd Concentration and Isotopic Data for Apollo 11 High-Ti Mare Basalts

\begin{tabular}{|c|c|c|c|c|c|c|c|c|c|c|c|c|c|c|}
\hline Sample & Group & $w t(m g)$ & $\mathrm{Rb}$ & Sr & ${ }^{87} \mathrm{Rb} /{ }^{86} \mathrm{Sr}^{1}$ & ${ }^{87} \mathrm{Sr}^{86} \mathrm{Sr}^{2}$ & ${ }^{87} \mathbf{S} x^{86} \mathrm{Sr}_{(\mathrm{i})}$ & $\mathrm{T}_{\text {LUNI }}(\mathrm{Ga})$ & $\mathrm{Sm}$ & $\mathrm{Nd}$ & ${ }^{147} \mathrm{Sm}^{144} \mathrm{Nd}^{*}$ & ${ }^{143} \mathrm{Nd} / 144 \mathrm{Nd}$ & $\varepsilon_{\mathrm{Na}}(\mathrm{T})$ & $\mathrm{T}_{\mathrm{CHUR}}$ \\
\hline & & & (ppm) & (apm) & & & & & $(\mathrm{ggm})$ & (ppm) & & & & \\
\hline 10017,345 & A & 15 & 6.27 & 179 & a.101 & $0.704653 \pm 13$ & $0.69942+2$ & $3.83 \pm 0.07$ & 21.9 & 63.9 & 0.2072 & $0.513043 \pm 09$ & $3.1 \pm 0.4$ & $5.73 \pm 0.23$ \\
\hline 10032,32 & A & 38 & 6.09 & 165 & 0.106 & $0.704932 \pm 17$ & $0.69946+2$ & $3.86 \pm 0.03$ & 22.2 & 65.0 & 0.2065 & $0.513031 \pm 09$ & $3.1 \pm 0.4$ & $5.95 \pm 0.26$ \\
\hline 10044,628 & B1 & 22 & 1.83 & 301 & 0.0176 & $0.700133 \pm 14$ & $0.69920 \pm 2$ & $4.34 \pm 0.08$ & 30.7 & 77.7 & 0.2387 & $0.514021 \pm 08$ & $7.1 \pm 0.4$ & $4.94+0.05$ \\
\hline 10047,217 & $\mathrm{Bl}$ & 14 & 0.898 & 200 & 0.0130 & $0.699857 \pm 13$ & $0.69917 \pm 2$ & $4.40 \pm 0.09$ & 13.8 & 34.1 & 0.2444 & $0.514174 \pm 09$ & $7.4 \pm 0.4$ & $4.84+0.06$ \\
\hline 10058,189 & BI & 15 & 1.42 & 193 & 0.0213 & $0.700306 \pm 14$ & $0.69918 \pm 2$ & $4.17 \pm 0.07$ & 21.9 & 54.8 & 0.2418 & $0.514120 \pm 07$ & $7.6 \pm 0.4$ & $4.93 \pm 0.05$ \\
\hline 10029,31 & $\mathrm{~B} 2$ & 23 & 0.367 & 134 & 0.00785 & $0.699631 \pm 21$ & $0.69920 \pm 3$ & $5.26 \pm 0.20$ & 9.31 & 25.5 & 0.2206 & $0.513354 \pm 10$ & $2.0 \pm 0.4$ & $4.49 \pm 0.05$ \\
\hline 10020,223 & B3 & 16 & 0.717 & 147 & 0.0141 & $0.699944 \pm 18$ & $0.69919+2$ & $4.51 \pm 0.11$ & 9.16 & 23.6 & 0.2348 & $0.513793 \pm 11$ & $4.3 \pm 0.4$ & $4.55 \pm 0.07$ \\
\hline 10045,108 & B3 & 28 & 0.701 & 136 & 0.0149 & $0.700021 \pm 13$ & $0.69923 \pm 2$ & $4,59 \pm 0.08$ & 8.92 & 23.0 & 0.2342 & $0.513776+12$ & $4.3 \pm 0.4$ & $4.56 \pm 0.08$ \\
\hline 10092,19 & $\mathrm{B3}$ & 18 & 0.678 & 139 & 0.0141 & $0.699944 \pm 14$ & $0.69919 \pm 2$ & $4,48 \pm 0.09$ & 8.60 & 22.1 & 0.2353 & $0.513818 \pm 07$ & $4.6 \pm 0.4$ & $4.59 \div 0.05$ \\
\hline 10050,162 & $\mathrm{U}$ & 20 & 0.706 & 183 & 0.0112 & $0.699712 \pm 13$ & $0.69912 \pm 2$ & $4.22 \pm 0.11$ & 123 & 30.2 & 0.2462 & $0.514237 \pm 09$ & $7.6 \pm 0.4$ & $4.85 \pm 0.05$ \\
\hline
\end{tabular}

\footnotetext{
${ }^{1}$ Errors are always $<0.6 \%$ relative,

${ }^{2}$ Absolute errors in measured ${ }^{87} \mathrm{Sz} /{ }^{86} \mathrm{Sr}$ and ${ }^{143} \mathrm{Nd} /{ }^{144} \mathrm{Nd}$ are quoted as 2 -sigma of the mean (intemal precision).

* Errors are always $<0.1 \%$ relative.
} 

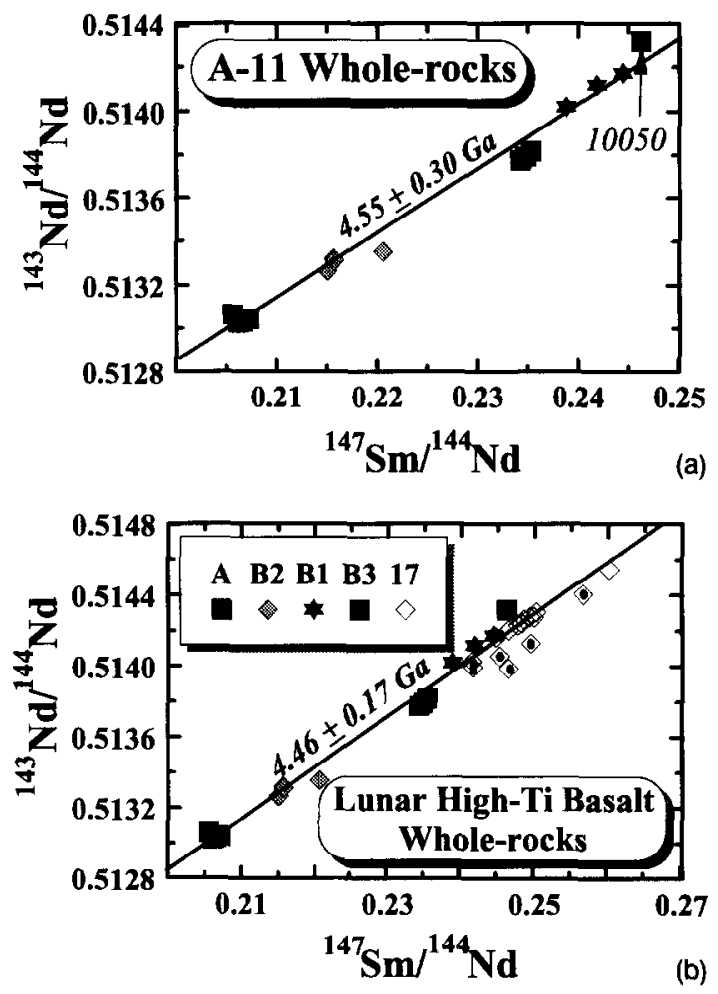

FIG. 5. ${ }^{147} \mathrm{Sm} /{ }^{144} \mathrm{Nd}$ vs. ${ }^{143} \mathrm{Nd} /{ }^{144} \mathrm{Nd}$ for lunar high-Ti basalts. a) linear regression of all Apollo 11 samples yields an "age" of 4.55 $\pm 0.30 \mathrm{Ga}$. The previously unclassified basalt, 10050 , lies above the line. b) linear regression of all high-Ti basalts from the Moon (cxcluding Apollo 17 Type B2 basalts-diamonds with dark dots; see text and PACES et al., 1991) yields an age of $4.46 \pm 0.17 \mathrm{Ga}$ and indicating the antiquity of the source(s). Isotopic ratios for Apollo 17 samples are reported relative to the same standard values as Apollo 11 data in the text.

et al. (1991) does not allow us to grant it much significance. The previously unclassified basalt, 10050 , does not lie within this array, but plots to lower ${ }^{87} \mathrm{Rb} /{ }^{86} \mathrm{Sr}$ and ${ }^{87} \mathrm{Sr} /{ }^{86} \mathrm{Sr}$.

For the most part, Sm-Nd isotopic data for the basalts exhibit tight clusters which correspond with previously determined types (A, B1, B2, and B3; see Table 3; Fig. 5). Remarkably, a regression of all fourteen whole-rock samples from Apollo 11 yields a line which exhibits the age of the Moon, $4.55 \pm 0.30 \mathrm{Ga}$ (MSWD = 70; Fig. 5a). The relatively large error in the line, as well as the large MSWD, indicate that the scatter cannot be due to analytical error alone and may indicate isotopically distinct sources for some samples. However, even if some of the scatter is due to statistical mixing of sources, the indication is that these sources were formed early in the history of the Moon. A regression of all high-Ti basalts from the Moon (with the exception of Type B2 basalts from Apollo 17; Type B2 basalts likely were contaminated during surface processes; PACES et al., 1991) gives a line which yields an age of $4.46 \pm 0.17 \mathrm{Ga}$ (MSWD $=45$; Fig. $5 \mathrm{~b}$ ). This whole-rock isochron can be taken as evidence that the source from which high-Ti basalts were derived had a relatively homogeneous ${ }^{143} \mathrm{Nd} /{ }^{144} \mathrm{Nd}$, yet variable $\mathrm{Sm} / \mathrm{Nd}$, at $4.4 \mathrm{Ga}$. Apollo 11 Group B1 hasalts plot slightly above the line and indicate a relatively long-lived depleted-mantle component.
The presence of a second component, which is large-ion lithophile-element (LILE)-enriched, is reflected in both the low ${ }^{147} \mathrm{Sm} /{ }^{144} \mathrm{Nd}$ values and high ${ }^{87} \mathrm{Rb} /{ }^{86} \mathrm{Sr}$ and $\mathrm{K}_{2} \mathrm{O}$ in Group A samples from Apollo 11.

Initial strontium isotopic ratios and $\epsilon_{\mathrm{Nd}}$ values have been calculated for each basalt sample assuming the average ages for each group as indicated in Table 1. These initial strontium isotopic ratios and $\epsilon_{\mathrm{Nd}}$ values are reported in Table 3 and plotted together with those from Apollo 17 in Fig. 6. Combined strontium and neodymium isotopic data indicate distinct fields for the different basalt types, although Group A basalts exhibit a relatively wide range in strontium initial ratios. These data alone suggest three plausible, competing interpretations: (1) four different sources for the Apollo 11 basalts, commensurate with their previously determined classification, (2) extreme heterogeneity in the lunar mantle leading to a multitude of sources (a variation on interpretation number one), or (3) real, albeit small, differences in the crystallization ages of samples from the same group. We have suggestcd above that cach basalt group represents a relatively restricted (within $20 \mathrm{Ma}$ ) magmatic event, and thus, interpretation number three would be obviated.

\section{DISCUSSION}

Apart from basalts from the Apollo 11 landing site, only those from Apollo 17 can be considered truly high-Ti in tenor (9-14 wt\% $\mathrm{TiO}_{2} ;$ NEAL and TAYLOR, 1992). The high-Ti basalts from Apollo 17 exhibit a more restricted range in age (3.69-3.75 Ga) than those from Apollo 11 (PACES et al., 1991). Neodymium and strontium isotopic data for the lunar high-Ti basalts yield a wide range of initial $\epsilon_{\mathrm{Nd}}$ and strontium isotopic signatures. Fields for the Apollo 11 Group Bl and B3 basalts differ by at least 2.5 epsilon units (Fig. 6). Basalts from Apollo 11, excluding the Group A basalts, plot at relatively low ${ }^{87} \mathrm{Sr} /{ }^{86} \mathrm{Sr}$ for a given $\epsilon_{\mathrm{Nd}}$ value, relative to those from Apollo 17. Apollo 11 Group B1 basalts have $\epsilon_{\mathrm{Nd}}$ values which are similar to Apollo $17 \mathrm{~A}, \mathrm{~B} 1$, and C basalts. However, all of these groups are distinct in strontium isotopic composition. Type B2 basalts from Apollo 17 have the most vari-

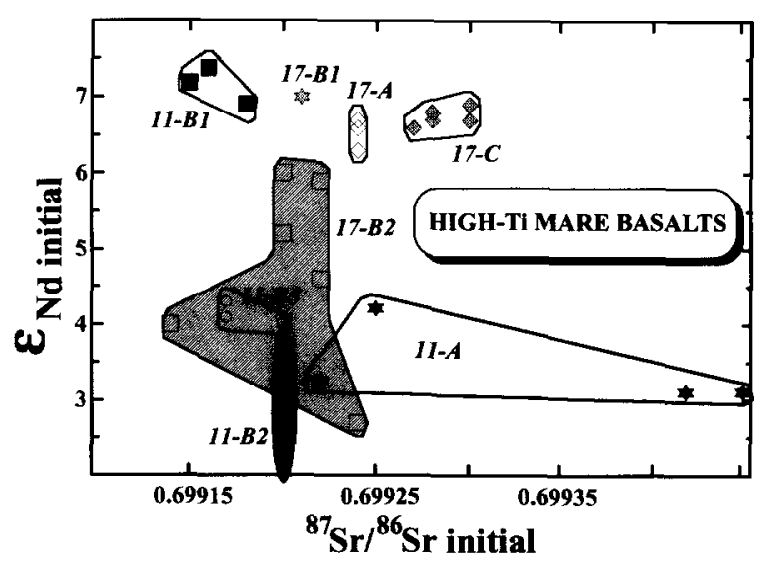

FIG. 6. Plot of initial ${ }^{87} \mathrm{Sr} /{ }^{86} \mathrm{Sr}$ vs. initial $\epsilon_{\mathrm{Nd}}$ for all high-Ti basalts from the Moon. Light shaded area encompasses all Type B2 basalt data from Apollo 17; dark shaded area encompasses all Apollo 11 B2 determinations. 
able neodymium and strontium isotopic compositions. Previous workers have interpreted much of this isotopic variability as due to heterogeneity in the sources of high-Ti basalts (e.g., PACEs et al., 1991). However, the major- and traceelement composition, and mineralogy are strikingly uniform for the Apollo 11 low-K (Groups B1, B2, and B3) basalts.

SNYDER et al. (1992) have noted the similarity in traceelement compositions between Type $C$ basalts from the Apollo 17 landing site and Group B3 basalts from the Apollo 11 landing site. They have inferred that these two basalt types were generated from the same source. Furthermore, JERDE et al. (1992a, 1994) have indicated that the Group BI basalts may have been derived from the Group B3 basalts by fractional crystallization (assuming that the groups are indeed the same age). This conclusion is supported by strontium isotopic modelling alone (Fig. 7). Assuming that the bulk distribution coefficient for strontium in these basalts is $<1$, Fig. 7 indicates that the $\mathrm{B} 3$ basalts are likely precursors to the $B I$ basalts and both may be related by simple fractional crystallization. However, ratios of the REEs (e.g., Fig. 8) demonstrate a distinct difference, both in the ${ }^{147} \mathrm{Sm} /{ }^{144} \mathrm{Nd}$ and ${ }^{143} \mathrm{Nd} /{ }^{144} \mathrm{Nd}$ of $\mathrm{BI}$ and $\mathrm{B} 3$ basalts. Fractional crystallization of a B3 basalt is not likely to produce a magma which has a higher $\mathrm{Sm} / \mathrm{Nd}$ and more radiogenic neodymium isotopic composition. Therefore, a different mechanism must be proposed to explain the isotopic systematics and traceelement ratios. Again, looking at the strontium modelling alone, $\mathrm{B} 2$ basalts could be part of the same fractionation sequence. However, the older age $(3.85 \mathrm{Ga})$ of $\mathrm{B} 2$ basalts precludes this relationship.

In summary, isotopic data suggest separate sources for the high."Ti basalts at Mare Tranquillitatis, whereas trace- and major-element modelling indicate a fractionation relationship between Groups B3 and B1 and broad source similarities for all high-Ti basalts except type A. Assuming the source(s) of high-Ti mare basalts exhibits an elevated $\mathrm{Sm} / \mathrm{Nd}$, any fractionation model based on trace- and major-elements which seeks to relate different groups of high-Ti basalts must include the addition (assimilation?) of at least a second component with low Sm/Nd. What could have caused this apparent de-

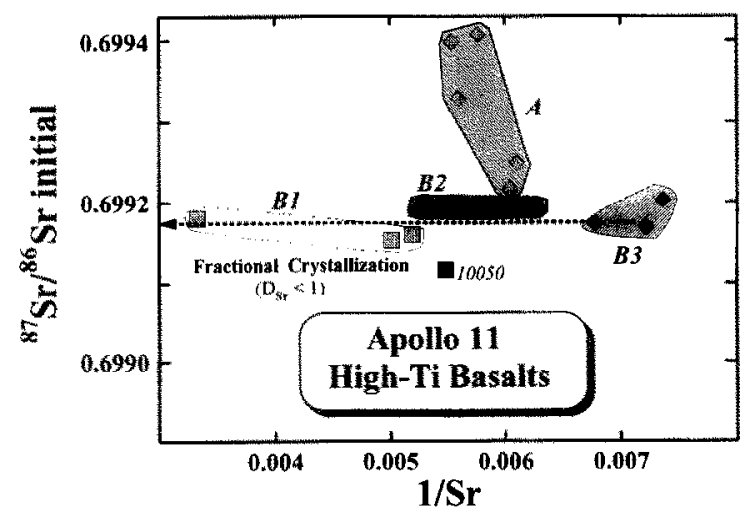

FIO. 7. Plot of $1 / \mathrm{Sr}$ vs. ${ }^{87} \mathrm{Sr} /{ }^{86} \mathrm{Sr}$ initial for the Apollo $1 /$ high-Ti basalts. An evolutionary array is plotted which is consistent with fractional cystallization of an assemblage which is incompatible with Sr (i.e... $\left.D_{\mathrm{s}}<1\right)$.

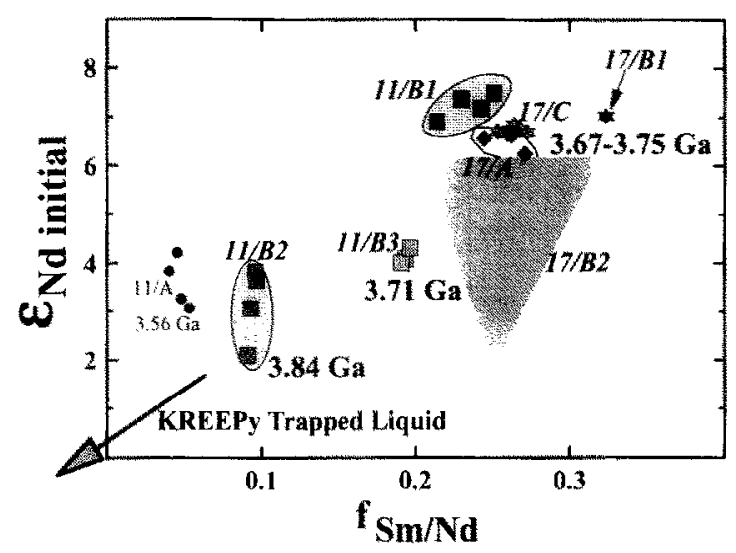

Fl. 8. Plot of $\mathrm{sm} / \mathrm{Nd}$ (ractionation of $\mathrm{Sm} / \mathrm{Nd}$ relative to chondritic $\mathrm{Sm} / \mathrm{Nd}$ ) versus initial $\epsilon_{\mathrm{Nd}}$ for all lunar high-T basalts. Ages are also indicated. in Ga, adjacent to the groups. Shaded region encompasses all Type B2 data from Apollo 17. KREEPy trapped liquid would project off the lower left of this diagram to negative $\mathrm{Ndd}_{\mathrm{d}}$ and $f_{\mathrm{Sm} / \mathrm{Nd}}$ values.

coupling of the isotopes from the major- and trace-element compositions?

First, the basalts could have been contaminated in transit to, or at, the lunar surface. Likely contaminants include anorthositic crust, lunar granite, or KREEP. Each of these plausible contaminants is LREE-enriched, although to different degrees. Indeed, previous workers have suggested that KREEP assimilation could explain the isotopic variability in some, though not all, high-Ti magmas (PACES et al., 1991). Second, the sources for the mare basalts could have been metasomatically altered. However, this metasomatism must have occurred early in the history of the reservoir(s), allowing metasomatized reservoirs to evolve along separate isotopic pathways for $0.5 \mathrm{Ga}$. This posited metasomatism also must have been highly selective for certain mantle source region(s) of the mare basalts, while others remained relatively untouched by metasomatizing agents.

The similarity of the low-K, high-Ti basalts in mineralogy, major-, and trace-elements has led to the suggestion that they were all derived from a similar, if not common, source (JERDE et al., 1992a,b, 1994). It is conceivable, for example, that all high-Ti basalts were generated from a similar portion of the Moon, progressively depleted by melting over a 250 Ma period. There is some evidence to support this hypothesis in Fig. 8, where the sources of high-Ti mare basalts do seem to become more depleted with time (again, excluding the Type A basalts). Using the initial neodymium isotopic composition of the basalts, the ${ }^{147} \mathrm{Sm} /{ }^{144} \mathrm{Nd}$ ratios of the source between postulated melting events can be calculated. However, an unrealistically high ${ }^{147} \mathrm{Sm} /{ }^{144} \mathrm{Nd}$ ratio $(>1)$ is required in the source in order to generate the $\epsilon_{\mathrm{Nd}}$ values of Apollo 17 Type B1 basalts at $3.69 \mathrm{Ga}$ from the same source as Apollo $11 \mathrm{B3}$ basalts $(3.71 \mathrm{Ga})$. Hence, the progressively depleted nature of the high-Ti mare basalts reflect a larger proportion of a long-lived LREE-depleted component in the source with time, and not progressive depletion due to melting. As can be seen in Fig. 8, this depleted component dominates many of these basalts after about $3.75 \mathrm{Ga}$. 
Model ages for the Apollo 11 basalts are, characteristically, older and younger than the Moon $(4.55 \mathrm{Ga}$ ) for neodymium and strontium, respectively (Table 3 ). Notable exceptions are the Group B3 basalts which exhibit model ages for both $\mathrm{Nd}(4.55-4.59 \mathrm{Ga})$ and $\mathrm{Sr}(4.51-4.59 \mathrm{Ga})$ coincident with the age of the Moon. This convergence of model ages for the B3 basalts is intriguing and could indicate a single-stage evolution for these rocks. All other basalts would indicate an enrichment "event" subsequent to the formation of the Moon and prior to their extrusion on the surface. Alternatively, this convergence of neodymium and strontium model ages with the age of the Moon for the B3 basalts may simply be a fortuitous consequence of mixing depleted and enriched reservoirs generated at the inception of the Moon.

PACES et al. (1991) attribute significance to a Rb-Sr wholerock isochron (of selected whole-rocks) which yields an age of $4.02 \pm 0.05 \mathrm{Ga}$. They suggest that this whole-rock isochron represents the final time that the sources for these basalts exhibited a common strontium isotopic composition. They postulated that the cause for later isotopic modification and divergence of the sources was due to metasomatic effects involving $\mathrm{Rb}$ - and halogen-rich fluids "derived either through outgassing of the lunar interior or through fractional crystallization of KREEPy magmas emplaced nearby" (PACES et al., 1991). We do not believe this to be the case for the Apollo 11 basalts. First, PACES et al. (1991) indicated a convergence of neodymium and strontium model ages, at 4.64.7 $\mathrm{Ga}$ in their Table 3, for the Type $\mathrm{C}$ basalts from the Apollo 17 landing site. This convergence is difficult to reconcile with their metasomatic addition model for generation of the elevated rubidium found in these samples (PACES et al., 1991). It seems improbable that just enough rubidium would be added to these rocks to yield strontium model ages coincident with those of neodymium. Second, the $\mathrm{Rb}-\mathrm{Sr}$ whole-rock "age" for the Apollo 11 basalts ( $3.74 \pm 0.07 \mathrm{Ga}$, MSWD $=14.6$; Fig. 4) is much younger than the Sm-Nd whole-rock "age" $(4.55 \pm 0.30 \mathrm{Ga}, \mathrm{MSWD}=70)$, in direct contrast to those for the Apollo 17 basalts. Third, the $\mathrm{Rb}-\mathrm{Sr}$ "isochron" for the Apollo 11 high-Ti basalts is, in effect, a two-point mixing array between low-K basalts (with low $\mathrm{Rb}$ / $\mathrm{Sr}$ and low ${ }^{87} \mathrm{Sr} /{ }^{86} \mathrm{Sr}$ values) and high-K basalts (with high $\mathrm{Rb} / \mathrm{Sr}$ and high ${ }^{87} \mathrm{Sr} /{ }^{86} \mathrm{Sr}$ values ) of demonstrably different origins (JERDE et al., 1994). Rb-Sr whole-rock systematics of the low-K basalts from Apollo 11 do hint at an "event" at between 3.85 and $4.10 \mathrm{Ga}$, in agreement with the $\mathrm{Rb}-\mathrm{Sr}$ data of PACES et al. (1991). However, the scatter in the array for Apollo 11 low-K basalts, and that for Apollo 17 basalts (if all samples are regressed), indicates a process which is much less systematic and which may have occurred over an extended time period.

It is interesting to note that intense meteoritic bombardment of the Moon likely began to taper off (some workers have stated evidence for a peak meteoritic bombardment at this time: the so-called "lunar cataclysm", TERA and WASSERBURG, 1974) during this time interval of 4.10 to $3.85 \mathrm{Ga}$ (RYDER, 1990). Continued intense meteoritic bombardment of the early Moon, in consort with the formation of an insulating megaregolith, could have allowed the deep interior of the Moon to remain hot for hundreds of millions of years (WARREN et al., 1991). It is hypothesized that the isotopic closure for the Sm-Nd system occurred early in the high-Ti basalt source region (at approximately $100 \mathrm{~km}$ depth, SNYDER and TAYLOR, 1993), whereas, closure for the Rb-Sr system may not have occurred until $\sim 4.0 \mathrm{Ga}$, due to heating by meteoritic bombardment and insulation of the interior by the megaregolith. Therefore, the whole-rock Sm-Nd and RbSr isochrons may be reflecting the times of final isotopic closure for the high-Ti source. Conversely, the scatter in the RbSr array for the Apollo 11 basalts (Fig. 4) and that for Apollo 17 (when all samples are included) could have been caused by later meteoritic impacts and/or metasomatism, and consequent volatile loss-addition of rubidium, after extrusion of the basalts onto the surface of the Moon.

\section{ORIGIN AND DEVELOPMENT OF THE LUNAR UPPER MANTLE}

Radiogenic isotope geochemistry of mare basalts has produced unequivocal evidence for at least two reservoirs in the upper mantle of the Moon, one extremely depleted and one enriched (PAPANASTASSIOU et al., 1977; UNRUH et al., 1984; NYQUIST and SHIH, 1992; NYQUIST et al., 1977). PAPANASTASSIOU et al. ( 1977) produced the first Sm-Nd isotopic data for high-Ti basalts and postulated that they were melted from a depleted reservoir, which was formed from cumulates of a lunar magma ocean at $4.4 \mathrm{Ga}$. These cumulates had a ${ }^{147} \mathrm{Sm} /$ ${ }^{144} \mathrm{Nd}=0.271$. The antiquity of the depleted source was based on both Rb-Sr and Sm-Nd model ages and the intersection of concordia at $4.42 \mathrm{Ga}$ for U-Pb data for the bulk of mare basalt and highlands samples (TERA and WASSERBURG, 1974). PAPANASTASSiOU et al. (1977) also suggested a complementary enriched reservoir that had ${ }^{147} \mathrm{Sm} /{ }^{144} \mathrm{Nd}=0.165$. Based on $\mathrm{Rb}-\mathrm{Sr}$ and $\mathrm{Sm}-\mathrm{Nd}$ isotopic and abundance data from both high-Ti basalts and ilmenite basalts from Apollo 12, NYQUIST et al. (1977, 1979) proposed a two-stage model for mare basalts, similar to that of PAPANASTASSIOU et al. (1977), albeit more detailed. NYQUIST et al. ( 1977) developed the concept of a lunar initial (LUNI) for strontium isotopes $\left({ }^{87} \mathrm{Sr} /{ }^{86} \mathrm{Sr}=0.69903\right)$ and PAPANASTASSIOU et al. (1977) suggested that the Moon began (at $4.6 \mathrm{Ga}$ ) with chondritic initial neodymium isotope ratios: ${ }^{143} \mathrm{Nd} /{ }^{144} \mathrm{Nd}=0.50667$. From 4.6 to $4.4 \mathrm{Ga}$, the lunar magma ocean was still crystallizing and evolving with ${ }^{87} \mathrm{Rb} /{ }^{86} \mathrm{Sr}=0.05$ and ${ }^{147} \mathrm{Sm} /{ }^{144} \mathrm{Nd}$ $=0.175$. The cumulate source $(\mathrm{s})$ for the high-Ti basalts was formed at $4.4 \mathrm{Ga}$ with ${ }^{87} \mathrm{Rb} /{ }^{86} \mathrm{Sr}=0.006$ and ${ }^{147} \mathrm{Sm} /{ }^{144} \mathrm{Nd}$ $=0.301$. A complementary enriched reservoir (the late-stage LMO liquid, manifested in KREEP) was also formed at this time with ${ }^{87} \mathrm{Rb} /{ }^{86} \mathrm{Sr}=0.205$ and ${ }^{147} \mathrm{Sm} /{ }^{144} \mathrm{Nd}=0.172$ (NYQUIST et al., 1979). With the accumulation of more data and refinement of models, these parent/daughter ratios have changed to ${ }^{87} \mathrm{Rb} /{ }^{86} \mathrm{Sr}=0.005$ (PACES et al., 1991) and ${ }^{147} \mathrm{Sm} /$ ${ }^{144} \mathrm{Nd}=0.260-290$ (UNRUH et al., 1984; AGEE and LONGHI, 1992 ) for the depleted cumulate reservoir, and ${ }^{87} \mathrm{Rb} /{ }^{86} \mathrm{Sr}$ $=0.235$ and ${ }^{147} \mathrm{Sm} /{ }^{144} \mathrm{Nd}=0.169$ for the enriched KREEPy reservoir (NYQUIST and SHIH, 1992).

Though a consensus has been reached on the antiquity and general character of these two reservoirs, their exact interaction during the formation of high-Ti basalt source(s), and subsequent generation of the basalts themselves, has been a point of contention. The broad range in initial neodymium and strontium isotopic ratios has led many workers to the 
conclusion that a variety of sources must be invoked. Magma mixing has been ruled out as a major process in the formation of separate sources and, therefore, other processes such as assimilation have been proposed to explain perceived heterogeneities (e.g., TERA and WASSERBURG, 1974; NYQUIST et al., 1977). Finally, many workers have suggested that these heterogeneities were "locked in" to the upper mantle at, or prior to, $4.4 \mathrm{Ga}$ (e.g., NYQuIST and SHIH, 1992). However, the cause for such heterogeneities has remained speculative.

\section{An Adcumulate-Trapped-Liquid Source Model}

It is generally believed that for less than the first $0.2 \mathrm{Ga}$ of its history, the Moon differentiated into a small Fe-rich core, an olivine-rich lower mantle, and a differentiated magma ocean (e.g., AGEE and LONGH, 1992). This outer magma ocean, or magmasphere, progressively crystallized to form the upper mantle of the Moon and, once plagioclase became a liquidus phase, its anorthositic crust. The crystallization of the magmasphere likely led to layering of the upper mantle and included phases, such as ilmenite, late in its differentiation. The residual liquid magmasphere became more evolved with time, leading to enrichment in the LILE. This LILEenriched liquid could have been trapped in variable, yet small, proportions and effectively "metasomatized" the relatively LILE-depleted crystallizing mafic cumulate. In this way, adjacent regions or layers of the mantle could maintain mineralogic and major-element homogeneity, while exhibiting heterogeneities in their trace elements.

A consistent and simple model for the cumulate source region of the high-Ti mare basalts is presented in Fig. 9-11. This model includes one adcumulate source for all high-Ti basalts (except the Apollo 11 Group A basalts). This type of source, involving a model perfect adcumulate with variable proportions of trapped liquid was a product of a global LMO. This original cumulate source contained a small $(<2 \%)$, yet variable, proportion of trapped liquid which, at the advanced stage of crystallization of the LMO, would have been KREEPy (SNYDER et al., 1992). SNYDER et al. (1992) have modelled

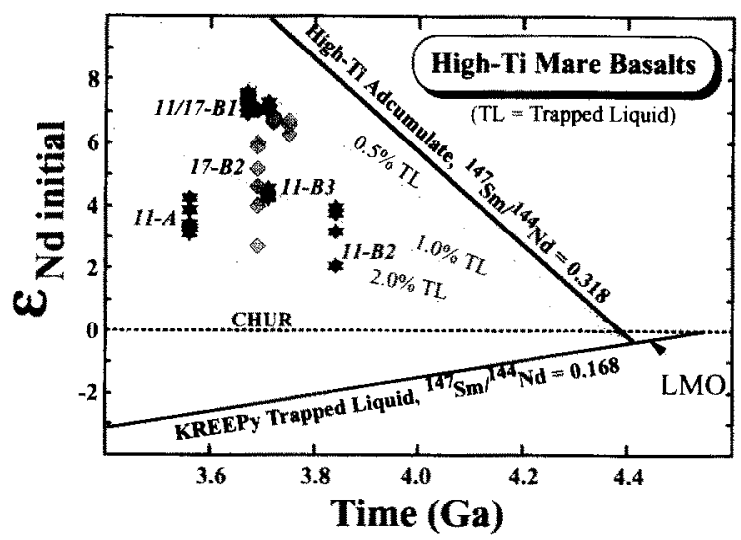

FIG. 9. Plot of initial $\epsilon_{\mathbb{N d}}$ vs. time (in Ga) for all high-Ti basalts. This plot shows the evolution line for a high-Ti perfect adcumulate $\left({ }^{147} \mathrm{Sm} /{ }^{144} \mathrm{Nd}=0.318\right)$ and those of adcumulates with successively more trapped KREEPy liquid $(0.5,1.0$, and $2.0 \%)$. The evolution of trapped KREEPy liquid (with a Sm/Nd ratio less than chondritic; ${ }^{147} \mathrm{Sm} /{ }^{144} \mathrm{Nd}=0.168$ ) would be such that it would exhibit more negative $\epsilon_{\mathrm{Nd}}$ values with time. Star symbols are for Apollo 11 samples. diamonds for Apollo 17 samples.

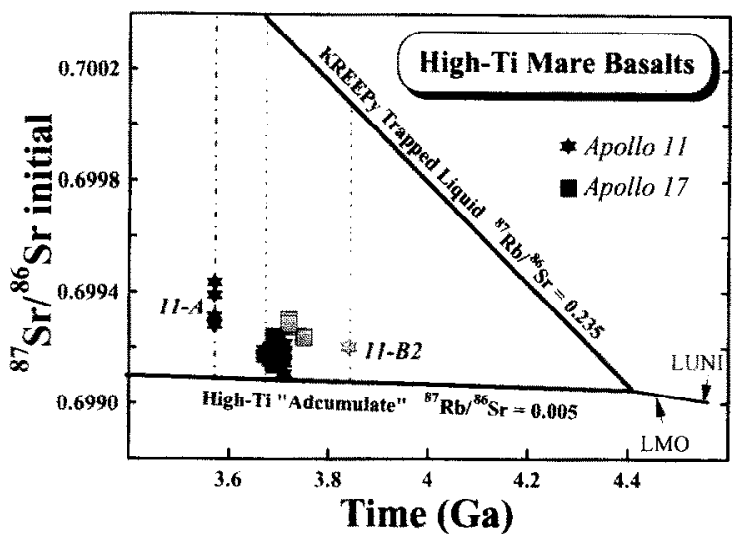

FiG. 10. Plot of time (in Ga) vs. ${ }^{87} \mathrm{Sr} /{ }^{86} \mathrm{Sr}$ initial for the high- $\mathrm{Ti}$ basalts. Also plotted are evolution arrays for KREEP $\left({ }^{87} \mathrm{Rb} /{ }^{86} \mathrm{Sr}\right.$ $=0.235)$ and a model high-Ti "adcumulate" $\left({ }^{87} \mathrm{Rb} /{ }^{86} \mathrm{Sr}=0.005\right)$. Symbols as in Figure 7.

trace- and major-elements during crystallization of the LMO, from its inception, until ilmenite became a liquidus phase at $>95 \%$ crystallization. However, they found that such a latecrystallizing cumulate was too deficient in magnesium to be a plausible source for the high-Ti basalts. Therefore, they proposed a model which included small-scale overturn of the lunar mantle above 86 Per Cent Solidified (PCS; after MORSE, 1979). The radial distance between this $86 \mathrm{PCS}$ layer and the ilmenite-bearing layer at $95 \mathrm{PCS}$ is only $20-30 \mathrm{~km}$ in a $300-400 \mathrm{~km}$ deep magma ocean. If small-scale convective overturn occurred during the formation of the mantle, then a proportion of the ilmenite-containing layer at 95 PCS could have sunken to, and mixed with, the mafic cumulate from the 86 PCS level. An 80:20 mixture of an 86 PCS cumulate with 95 PCS cumulate yields a mafic cumulate with an $\mathrm{Mg} \#$ of 0.73 . The mineralogy of this mafic cumulate is: $46 \%$ pigeonite $+43 \%$ olivine $+7 \%$ clinopyroxene $+3 \%$ ilmenite $+1 \%$ plagioclase (and a small ( $1-2 \%$ ) proportion of interstitial trapped KREEPy liquid from the 95 PCS level). This mafic cumulate was proposed as a viable source for the highTi basalts (SNYDER et al., 1992).

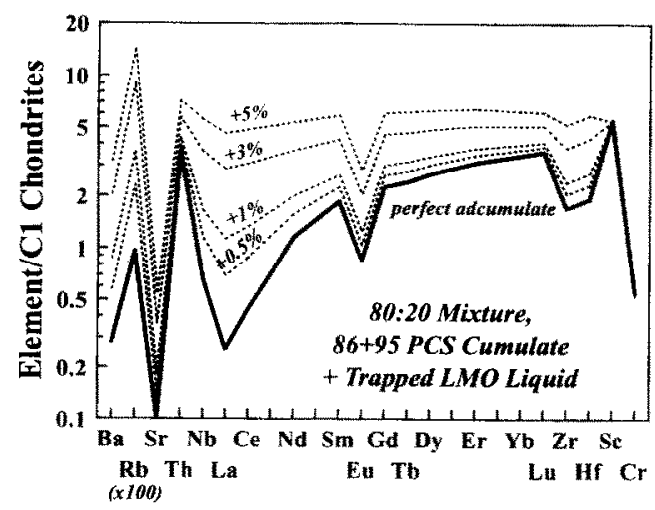

FKG. 1 1. Plot of selected elements normalized to Cl chondrites for a model mafic perfect adcumulate from a lunar magma ocean. This adcumulate is an 80:20 mixture of 86 PCS and 95 PCS cumulates from the lunar magma ocean, as per SNYDER et al. (1992). Also shown are mixtures of this adcumulate with $0.5,1,3$, and $5 \%$ KREEPy trapped liquid ( $F=0.005,0.01,0.03$, and 0.05 , respectively) from the 95 PCS level. 
The LILE-enriched, trapped liquid endmember of the source is represented by residual liquid after $95 \%$ crystallization of the LMO (as per SNYDER et al., 1992). The REE content of the KREEPy residual liquid at 95 PCS would be similar to that in basalt 15382; therefore, we will assume that the isotopic composition of, and trace-element abundances in, 15382 are also a good approximation to those in the residual liquid at that stage $(\mathrm{Rb}=16 \mathrm{ppm}, \mathrm{Sr}=195 \mathrm{ppm}$, ${ }^{87} \mathrm{Sr} /{ }^{86} \mathrm{Sr}(3.85 \mathrm{Ga})=0.70115 ; \mathrm{Sm}=31 \mathrm{ppm}, \mathrm{Nd}=112$ ppm, $\epsilon_{\text {Nd }}(3.85)=-3$; PAPANASTASSIOU and WASSERBURG, 1971; NYQUIST et al., 1979). The 80:20 mixture, $86+95$ PCS, cumulate portion of the source has a chemical composition of: $\mathrm{Rb}=0.022 \mathrm{ppm}, \mathrm{Sr}=0.78 \mathrm{ppm}, \mathrm{Sm}=0.27$ ppm, $\mathrm{Nd}=0.52 \mathrm{ppm}$ (again as per SNYDER et al., 1992; Fig. 9-11) and has an extremely elevated $\epsilon_{\mathrm{Nd}}(+8$ at $3.85 \mathrm{Ga})$ and the lowest strontium initial ratio $(0.69910)$ at $3.85 \mathrm{Ga}$. However, it is not likely that these two components remained distinct over a period of $500 \mathrm{Ma}$, when the interior of the Moon was still hot (WARREN et al., 1991). Recrystallization of the cumulate-trapped liquid pile could have occurred yielding a source which was heterogeneous in trace elements on the scale of meters. Due to the low $\mathrm{Sm} / \mathrm{Nd}$ ratio of the trapped liquid relative to the cumulate, those portions of the mantle which contained a larger proportion of this component would evolve with more enriched isotopic signatures (Figs. 9-10).

After an extended period of evolution (e.g., $>0.5 \mathrm{Ga}$ ), earliest melting of the trapped liquid-cumulate pair would, likely, affect regions which were relatively enriched in the LILE (containing heat-producing elements uranium, thorium, and potassium). Therefore, those regions which trapped the largest proportion of residual LMO liquid would melt first (Figs. 8,9). Melts of these regions would exhibit relatively enriched isotopic signatures. Later melting would tap regions with less trapped liquid and would yield more isotopically depleted melts (Figs. 8, 9). Obviously, the degrees of enrichment and depletion of the melts are highly dependent upon the proportion of trapped liquid and the extent of melting of the cumulate + trapped-liquid pile. However, the trapped liquid component is LILE-enriched (generally, by at least an order of magnitude over the mafic cumulate) and would have originally consisted of low-temperature melting phases that would readily remelt. Therefore, even a small proportion (e.g., $1 \%$ ) in the cumulate pile will greatly affect the isotopic signature of initial derived melts (Fig. 9). However, because of its small proportion, the trapped liquid would have a lesser effect (inversely proportional to the degree of melting) on the major-element composition of the melt.

The low ${ }^{147} \mathrm{Sm} /{ }^{144} \mathrm{Nd}$ of this KREEPy trapped liquid, in consort with the relatively high abundances of strontium and neodymium, obviate a large proportion of trapped liquid in the source. This is illustrated in Fig. 11, where small proportions $(\leq 5 \%)$ of trapped liquid have been added to a model high-Ti adcumulate. This addition of trapped liquid has the effect of lowering the $\mathrm{Sm} / \mathrm{Nd}$ ratio, yet increasing the abundances of strontium and neodymium, thereby leading to a viable cumulate source region. Again, only $2-3 \%$ of trapped liquid is required in the source for modal melting, and less if the trapped liquid is an early melting component (if the source was not recrystallized ).

This can be further appreciated by looking at the parent/

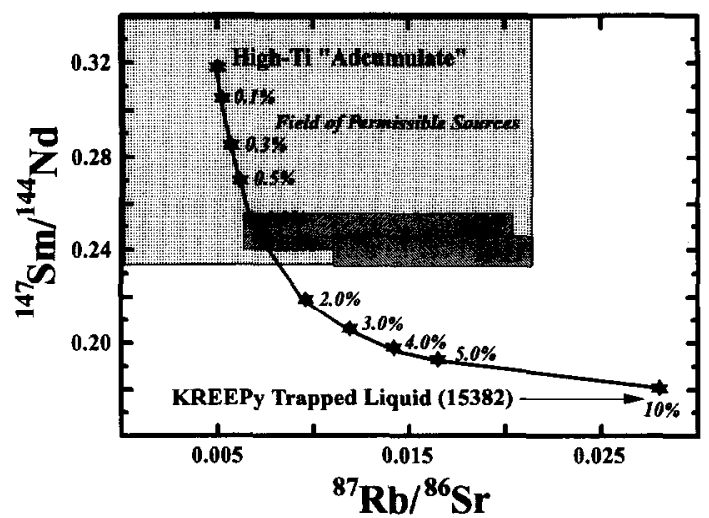

FIG. 12. Parent/daughter ratio plot of ${ }^{87} \mathrm{Rb} /{ }^{86} \mathrm{Sr}$ vs. ${ }^{147} \mathrm{Sm} /{ }^{144} \mathrm{Nd}$ indicating a mixing curve for the model high-Ti adcumulate $\left({ }^{147} \mathrm{Sm} /\right.$ $\left.{ }^{144} \mathrm{Nd}=0.318,{ }^{87} \mathrm{Rb} /{ }^{86} \mathrm{Sr}=0.005\right)$ and a KREEPy trapped liquid ( represented by $15382 ;{ }^{147} \mathrm{Sm} /{ }^{144} \mathrm{Nd}=0.168,{ }^{87} \mathrm{Rb} /{ }^{86} \mathrm{Sr}=0.235$ ). Star marks along the curve indicate percentages of KREEPy trapped liquid. Fields for measured ratios of low-K high-Ti basalts from Apollo 11 and 17 are also shown. The displacement of these fields to the right of this curve is due to fractional crystallization within the flow unit or in transit to the surface.

daughter ratios of the high-Ti basalts (Fig. 12; diagonally hatched areas). Simple two-component mixing of a high-Ti "adcumulate" source with varying percentages of KREEPy trapped liquid (where sample 15382 represents the KREEPy liquid) yields a curve of chemical mixtures. The compositions of the sources of the high-Ti basalts from both Apollo 11 and Apollo 17 should lie along this curve. Any source that contains residual mafic minerals, such as pigeonite, clinopyroxene, and olivine, would be more depleted (lower in ${ }^{87} \mathrm{Rb} /{ }^{86} \mathrm{Sr}$ and higher in ${ }^{147} \mathrm{Sm} /{ }^{144} \mathrm{Nd}$ ) than the basalts from which it was generated. With increasing fractional crystallization, rubidium is much more rapidly enriched in the residual liquid than samarium, neodymium, or strontium, and neodymium is only very slightly enriched relative to samarium. Therefore, the actual fractionatcd high-Ti basalts would lie along a nearly horizontal array to the right of this model curve and be displaced from the curve in proportion to their degree of fractionation. The field of permissible sources for high-Ti basalts (shaded) indicates $<1.5 \%$ trapped liquid. Although this trapped KREEPy liquid is minor in volume, it controls the radiogenic isotope signature of the derivative melt.

Similar calculations to discern the proportion of KREEP in these basalts were performed by HUGHES et al. (1989) and PACES et al. (1991). Both groups concluded that small percentages (generally $<1 \%$ ) of a rubidium, strontium, and LREE-enriched component, with high $\mathrm{Rb} / \mathrm{Sr}$ and low $\mathrm{Sm} /$ $\mathrm{Nd}$ ratios are required to explain the compositions of parental magmas for the high-Ti basalts. However, both groups envisioned this component as distal to the cumulate source and added to the source prior to its fusion, but not consequent with its inception. PACES et al. (1991) pointed out the problems inherent in such a scenario, but neither group explored the possibility of an ancient KREEPy reservoir which was spatially associated with the cumulate source-as trapped intercumulus liquid from the late stage of evolution of the LMO-since its inception at $\sim 4.4 \mathrm{Ga}$. The KREEPy component is, therefore, consanguineous with the mafic cumulate. 
Extension of the Model to 3.2 Ga: Evolution of Apollo 12 Ilmenite Basalts

It has been shown that high-Ti basalt volcanism over a period of almost $300 \mathrm{Ma}$, from 3.85 to $3.59 \mathrm{Ga}$, at the Apollo 11 and 17 landing sites can be explained by a simple twocomponent, single source, melting model. However, there is evidence that this source may have been tapped at an even later time in the history of the Moon. The ilmenite basalts from Apollo 12 have been dated at $3.2 \mathrm{Ga}$ (NYQUIST et al., $1979)$ and also are comparatively enriched in $\mathrm{TiO}_{2}(3-5 \%$ $\mathrm{TiO}_{2}$ ), though not to the extent of the high-Ti basalts. The ilmenite basalts display the most depleted isotopic signatures from the Apollo 12 landing site (NYQUIST et al., 1979), and in fact, the most depleted signatures on the Moon.

As indicated on Fig. 13, these ilmenite basalts lie along an extension of a depleted upper mantle "adcumulate" $(\sim 0.6 \%$ trapped liquid line) which generated the high-Ti basalts at the Apollo 11 and 17 landing sites. Furthermore, there is an indication that the source of these basalts contains less trapped KREEPy liquid than that for the earliest high-Ti basalts (i.e., Apollo 11 B-2 basalts). The Apollo 12 ilmenite basalts could represent the melting of a similar source to the high-Ti basalts which has been nearly (but not totally) depleted in both its trapped liquid and ilmenite components. Nonmodal, partial melting of such a source, with the remaining ilmenite making up a significant proportion of the melt, could lead to basalts which precipitate ilmenite, but not in the proportion found in high-Ti basalts from the Apollo 11 and 17 landing sites. The extension of the same or a similar high-Ti source beneath the western portion of the lunar near-side hinges on the identification of older high-Ti basalts near the Apollo 12 landing site. Such high-Ti basalt rocks have not been found in the Apollo 12 collection. However, ultraviolet/visible spectral imaging of Oceanus Procellarum (within which the Apollo 12 landing site is located) by the Galileo spacecraft has indicated the presence of widespread high- to low-Ti basaltic flows in the basin (SUNSHINE et al., 1992). Studies of Whitaker color-difference photographs of the lunar near-side led CHARETTE et al. (1974) to classify one of the stratigraphically

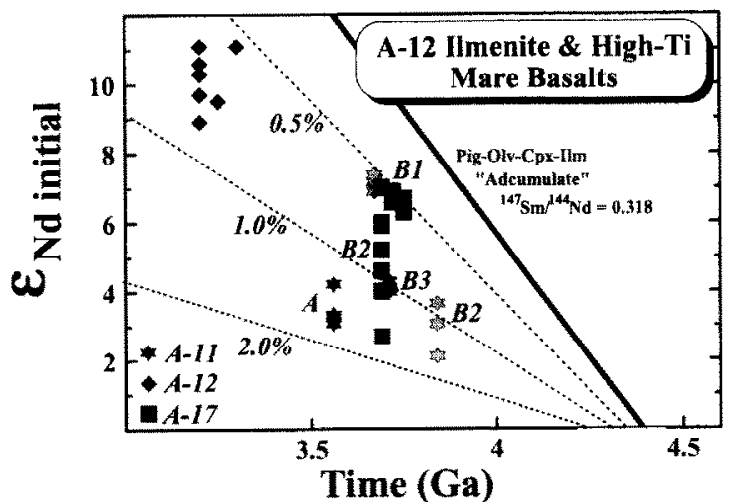

FIG. 13. Plot of time (in Ga) vs. initial $\epsilon_{\mathrm{Nd}}$ for all high-Ti mare basalts and the ilmenite basalts from Apollo 12. Lines of constant proportions of KREEPy trapped liquid $(0.5,1$, and $2 \%)$ over time are also indicated. An array for evolution of the model perfect adcumulate $\left({ }^{147} \mathrm{Sm} /{ }^{144} \mathrm{Nd}=0.318\right)$ is shown; the KREEP array would project off and below this diagram. oldest mare units in the basin as high-Ti in character. Therefore, it is considered plausible that older high-Ti basaltic volcanism, similar in character to that at the Apollo 11 and 17 landing sites, occurred prior to extrusion of the ilmenite basalts at the Apollo 12 landing site.

\section{SUMMARY}

Isotopic heterogeneilies in the source of low-K, high-Ti mare basalts could be the consequence of events unique to the Moon. In the late stages of LMO crystallization, when ilmenite was a liquidus phase, upper mantle cumulates trapped variable, yet small, amounts of residual LMO liquid. A lack of recycling in the lunar environment would allow these slightly different portions of essentially the same source to diverge along separate isotopic cvolutionary paths. Adcumulates with more trapped liquid would have higher contents of the heat-producing elements uranium, thorium, and potassium, and would likely melt first. Therefore, the earliest phase of volcanism at the Apollo 11 landing site $(3.85 \mathrm{Ga}$ ago, Group B2 and possibly D) involved the melting of a source which was relatively enriched in this KREEPy trapped liquid and the resultant magmas were slightly more aluminous, less titaniferous, and possessed a lower $\mathrm{Mg} \#$ than the later $\mathrm{B} 3$ basalts. These observations are consistent with these basalts being melted from a source which was relatively enriched in trapped KREEPy liquid. The volume of this KREEPy trapped liquid (or contaminant) would be small, but, because of its high LILE content, could greatly affect the isotopic ratios of basaltic magmas that would have intruded through the upper crust en route to the surface of the Moon. The next phase of volcanism (3.71-3.67 Ga, Groups B3 $\rightarrow$ B1) began by melting a portion of essentially the same source which contained a smaller proportion of KREEPy trapped liquid component. The presence of a continuum of compositions for the B1-B3 basalts is evidence that a number of individual flows have been sampled, a possibility noted by BEATY and ALBEE (1980), based on cooling rate considerations. Successive melting events included regions of the mafic adcumulate which contained less and less trapped liquid, producing magmas with progressively more depleted signatures. Apollo 12 ilmenite basalts may represent the final known melting of this cumulate source, after it nearly has been exhausted of its ilmenite and trapped liquid.

Acknowledgments-We appreciate the careful and timely work of both the LAPST (CAPTEM) committee and the curatorial staff at the Johnson Space Center, Houston. We also acknowledge with gratitude the use of facilities in the mineral separations lab provided by Samuel B. Mukasa and the assistance of John Encarnacion and Dave Palais, all at the University of Michigan. Careful reviews by Wayne Premo, Clive Neal, Larry Nyquist, Mark Ghiorso, and Brian Beard have greatly improved the clarity of the presentation. This study was supported by NASA grant NAG 9.415 to L. A. Taylor and NSF grants $90-04133$ and $91-04877$ to A. N. Halliday.

Editorial handling: M. S. Ghiorso

\section{REFERENCES}

AGEE C. B. and LONGHi J. (ed.) (1992) Workshop on the Physics and Chemistry of Magma Oceans from I bar to 4 Mbar. LPI Tech. Rpi. 92.03. Lunar Planet. Inst.

AlbEE A. L. and CHODOS A. A. (1970) Microprobe investigations 
of Apollo 11 samples. Proc. Apollo 11 Lunar Science Conf., 135 157.

BeATY D. W. and ALBEe A. L. (1978) Comparative petrology and possible genetic relations among the Apollo 11 basalts. Proc. 9th Lunar Planet. Sci. Conf., 359-463.

BEATY D. W. and ALBEE A. L. (1980) The geology and petrology of the Apollo 11 landing site. Proc. 11th Lunar Planet. Sci. Conf., 23-35.

BeATy D. W., Hill S. M. R., Albee A. L., MA M.-S., and SChmitT R. A. (1979) The petrology and chemistry of basaltic fragments from the Apollo 11 soil, part I. Proc. 10th Lunar Planet. Sci. Conf., 41-75.

BINDER A. B. (1982) The mare basalt magma source region and mare basalt magma genesis. Proc. 13th Lunar Planet. Science Conf., A37-A53.

BiNDER A. B. (1985) Mare basalt genesis: Modelling trace elements and isotopic ratios. Proc. 16th Lunar Planet. Science Conf., D19D30.

Charette M. P., McCord T. B., Pieters C. M., and Adams J. B. (1974) Application of remote spectral reflectance measurements to lunar geology classification and determination of titanium content of lunar soils. J. Geophys. Res. 79, 1605-1613.

COMPSTON W., Chappell B. W., ARRIENS P. A., and Vernon M. J. (1970) The chemistry and age of Apollo 11 lunar material. Proc. Apollo 11 Lunar Science Conf., 1007-1028.

DEPAOLO D. J. (1976) Nd isotopic variations and petrogenetic modcls. Geophys. Res. Lett. 3, 249-252.

Drake M. J. and Consolmagno G. J. (1976) Critical review of models for the evolution of high-Ti mare basalts. Proc. 7 th Lunar Sci. Conf., 1633-1657

Gast P. W., Hubbard N. J., and WiesmanN H. (1970) Chemical composition and petrogenesis of basalts from Tranquillity Base. Proc. Apollo 11 Lunar Sci. Conf. 1143-1163.

Geiss J., Eberhardt P., Grögler N., Guggisberg S., Maurer P., and STETTLER A. (1977) Absolute time scale of lunar mare formation and filling. Phil. Trans. Royal Soc. London A285, 15I158

Green D. H., Ringwood A. E., Ware N. G., Hibberson W. O., MAJOR A., and KISS E. (1971) Experimental petrology and petrogenesis of Apollo 12 basalts. Proc. 2nd Lunar Science Conf., 601-615.

GUGGISBERG S. et al. (1979) Classification of the Apollo 11 mare basalts according to ${ }^{39} \mathrm{Ar}-{ }^{40} \mathrm{Ar}$ ages and petrological properties. Proc. IOth Lunar Planet Sci Conf 1-39.

HARTMANN W. K. and DAvis D. R. (1975) Satellite-sized planetesimals and lunar origin. Icarus 24, 504-515.

Hubbard N. J. and Minear J. W. (1976) Petrogenesis in a moderately endowed moon. Proc. 7th Lunar Science Conf. 3421-3437.

Hughes S. S., Delano J. W., and SCHMitT R. A. (1989) Petrogenetic modeling of 74220 high-Ti orange volcanic glasses and the Apollo 11 and 17 high-Ti mare basalts. Proc. 19th Lunar Planet. Sci. Conf., 175-188.

Jerde E. A., SNyder G. A., and TAYlor L. A. (1992a) Apollo 11 low-K basalts: A single source and REEP contamination. Lunar Planet. Sci. XXIII, 611-612.

JERDE E. A., SNYDER G. A., and TAYLOR L. A. (1992b) Apollo 11 High-K Basalts: An Apollo 17 connection and evidence for neoKREEP. Lunar Planet. Sci. XXIII, 609-610.

JERDE E. A., SNYDER G. A., and TAYLOR L. A. (1994) The origin and evolution of lunar high-Ti basalts: Periodic melting of a single source at Mare Tranquillitatis. Geochim. Cosmochim. Acta 58, 515-527.

LUDWIG K. L. (1990) ISOPLOT: A Plotting and Regression Program for Radiogenic-Isotope Data, for IBM-PC Compatible Computers, V'ersion 2.01; USGS Open-file Report 88-557.

MA M.-S., SCHMitT R. A., BEATY D. W., and ALBEe A. L. (1980) The petrology and chemistry of basaltic fragments from the Apollo 11 soil: Drive tubes 10004 and 10005. Proc. 11th Lunar Planet. Sci. Conf., 37-47.

Melosh H. J. (1990) Giant impacts and the thermal state of the early Earth. In Origin of the Earth (ed. H. E. NEwSOM and J. H. JONES), pp. 69-83. Oxford Univ. Press.

MinSTER J.-F., BiRCK J.-L., and ALLEGRE C. J. (1982) Absolute age of formation of chondrites studied by the ${ }^{87} \mathrm{Rb}^{-87} \mathrm{Sr}$ method. Nature 300, 414-419.

MORSE S. A. (1979) Kiglapait geochemistry: I. Systematics, sampling, and density. J. Petrol. 20, 555-590.

NEAL C. R. and TAYLOR L. A. (1989) Metasomatic products of the lunar magma ocean: The role of KREEP dissemination. Geochim. Cosmochim. Acta 53, 529-541.

NEAL C. R. and TAYLOR L. A. (1992) Petrogenesis of mare basalts: A record of lunar volcanism. Geochim. Cosmochim. Acta 56, 21772211.

NYQUIST L. E. (1977) Lunar Rb-Sr chronology. Phys. Chem. Earth $10,103-142$

NYQUisT L. E. and SHIH C.-Y. ( 1992) On the chronology and isotopic record of lunar basaltic volcanism. Geochim. Cosmochim. Acto 56, 2213-2234

Nyquist L. E., Hubbard N. J., Gast P. W., Bansal B. M., WiesMANN H., and JAHN B. (1973) Rb-Sr systematics for chemically defined Apollo 15 and 16 materials. Proc. 4th Lunar Sci. Conf. 1823-1846.

Nyquist L. E., BanSal B. M., and WeismanN H. (1976) Sr isotopic constraints on the petrogenesis of Apollo 17 mare basalts. Proc. 7th Lunar Sci. Conf. 1507-1528.

Nyquist L. E., BanSAL B. M., WoOden J. L., and WiesmanN H. (1977) Sr-isotopic constraints on the petrogenesis of Apollo 12 mare basalts. Proc. 8th Lunar Sci. Conf. 1383-1415.

NYQUist L. E., SHiH C.-Y., WoOden J. L., BanSAL B. M., and WIESMANN H. (1979) The Sr and Nd isotopic record of Apollo 12 basalts: Implications for lunar geochemical evolution. Proc. I0th Lunar Planet. Sci. Conf., 77-114.

Nyquisi L. E., Takeda H., Bansal B. M., Shih C.-Y., WitsmanN H., and WOODEN J. L. (1986) Rb-Sr and Sm-Nd internal isochron ages of a subophitic basalt clast and a matrix sample from the Y75011 eucrite. J. Geophys. Res. 91, 8137-8150.

Paces J. B., Nakai S., Neal C. R., Taylor l. A., Halliday A. N., and LEE D. C. (1991) A strontium and neodymium isotopic study of Apollo 17 high-Ti mare basalts: Resolution of ages, evolution of magmas, and origins of source heterogeneities. Geochim. Cosmochim. Acta 55, 2025-2043.

PAPANASTASSIOU D. A. and WASSERburg G. J. ( 1971 ) Lunar chronology and evolution from Rb-Sr studies of Apollo $1 \mathrm{l}$ and Apollo 12 samples. Earth Planet. Sci. Lett. 11, 37-62.

Papanastassiou D. A., Depaolo D. J., and Wasserburg G. J. (1977) Rb-Sr and Sm-Nd chronology and genealogy of mare basalts from the Sea of Tranquillity. Proc. 8th Lunar Sci. Conf.. 16391672

Philpotts J. A. and Schnetzler C. C. (1970) Apollo 11 lunar samples: $\mathrm{K}, \mathrm{Rb}, \mathrm{Sr}, \mathrm{Ba}$, and rare-earth concentrations in some rocks and separated phases. Proc. Apollo 11 Lunar Sci. Conf., 14711486.

RhODES J. M. and Blanchard D. P. (1980) Chemistry of Apollo 11 low-K mare basalts. Proc. 11th Lunar Planet. Sci. Conf., 4966.

Ringwood A. E. and Essene E. (1970) Petrogenesis of Apollo 11 basalts, internal constitution and origin of the moon. Proc. Apollo 11 Lunar Sci. Conf., 769-799.

RiNGwoOd A. E. and Kesson S. E. (1976) A dynamic model for mare basalt petrogenesis. Proc. 7th Lunar Science Conf., 16971722.

RYDER G. (1990) Lunar samples, lunar accretion and early bombardment of the Moon. EOS 71, 313-323.

SHIH C.-Y. and SCHONFELD E. (1976) Mare basalt genesis: A cumulate-remelting model. Proc. 7th Lunar Sci. Conf., 1757-1792.

SHIH C.-Y., NYQUIST L. E., BANSAL B. M., and WIESMANN H. (1992) $\mathrm{Rb}-\mathrm{Sr}$ and $\mathrm{Sm}-\mathrm{Nd}$ chronology of an Apollo 17 KREEP basalt. Earth Planet. Sci. Lett. 108, 203-215.

SMITH J. V. et al. (1970) Petrologic history of the Moon inferred from petrography, mineralogy, and petrogenesis of Apollo 11 rocks. Proc. Apollo 11 Lunar Sci. Conf., 897-925.

SNYDER G. A. and TAYLOR L. A. (1993) Constraints on the genesis and evolution of the Moon's magma ocean and derivative cumulate sources as supported by lunar meteorites. Proc. NIPR Symp. Antarctic Meteorites 6, 246-267.

SNYDER G. A., TAYlor L. A., and NEAL C. R. (1992) A chemical 
model for generating the sources of mare basalts: Combined equilibrium and fractional crystallization of the lunar magmasphere. Geochim. Cosmochim. Acta 56, 3809-3823.

STEIGER R. H. and JAEGER E. (1977) Subcommission on geochronology: Convention on the use of decay constants in geo- and cosmochronology. Earth Planet. Sci. Lett. 36, 359-362.

Stettler A., Eberhardt P., Geiss J., Grogler N., and Maurer P. (1974) On the duration of lava flow activity in Mare Tranquillitatis. Proc. 5th Lunar Sci. Conf., 1557-1570.

Sunshine J. M., Pieters C. M., and Head J. W. (1992) Occanus Procellarum as viewed by Galileo: Evidence for compositional diversity in the mare deposits and at the Marius Hills Plateau. Lunar Planet Sci. XXIII, 1387-1388.

TAYLOR S. R. (1982) Planetary Science: A Lunar Perspective. Lunar and Planetary Institute.

TAYLOR S. R. and JAKES P. (1974) The geochemical evolution of the Moon. Proc. 5th Lunar Science Conf.. 1287-1305.
TERA F. and WASSFRRUIRG G. J. (1974) U-Th-Pb systematics on lunar rocks and inferences about lunar evolution and the age of the Moon. Proc. 5th Lunar Sci. Conf., 1571-1599.

Unruh D. M., Stille P., Patchett P. J., and TAtsumoto M. (1984) Lu-Hf and Sm-Nd evolution in lunar mare basalts. Proc. 14th Lunar Planet. Sci. Conf., B459-B477.

WALKER D., LONGHI J., and HAYS J. F. (1975) Differentiation of a very thick magma body and implications for the source regions of mare basalts. Proc. 6th Lunar Sci. Conf., 1103-1120.

WARREN P. H. and WASSON J. T. (1979) The origin of Kreep. Rev. Geophys. Space Phys. 17, 73-88.

Warren P. H., HaACK H., and Rasmussen K. L. (1991) Megaregolith insulation and the duration of cooling to isotopic closure within differentiated asteroids and the Moon. J. Geophys. Res. 96, $5909-5923$.

YORK D. ( 1969 ) Least-squares fitting of a straight line with correlated errors. Earth Planet. Sci. Lett. 5, 320-324. 